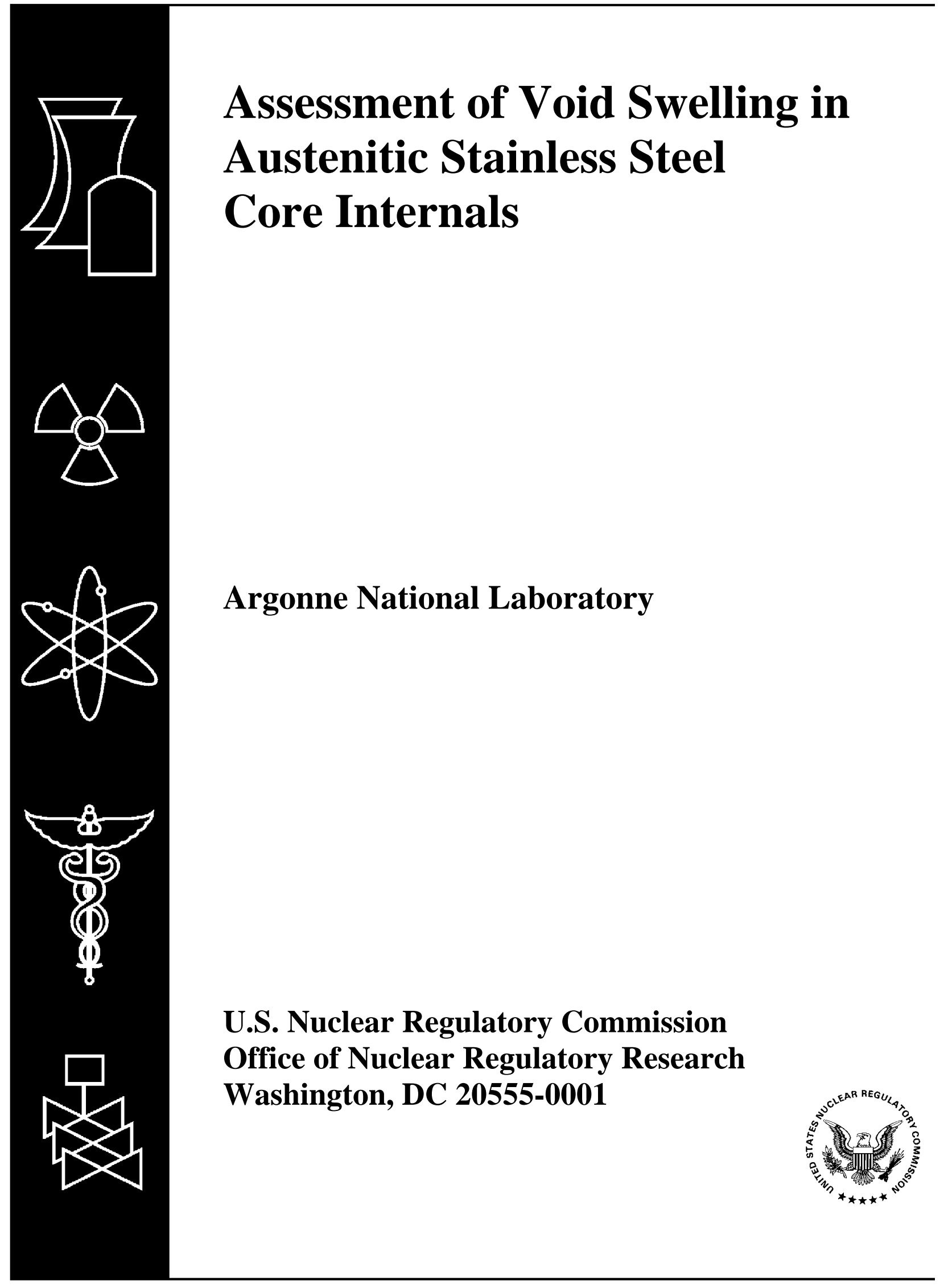




\section{Assessment of Void Swelling in Austenitic Stainless Steel Core Internals}

Manuscript Completed: December 2004

Date Published: January 2006

Prepared by

H. M. Chung

Energy Technology Division

Argonne National Laboratory

9700 South Cass Avenue

Argonne, IL 60439

W. H. Cullen, Jr., NRC Project Manager

\section{Prepared for}

Division of Engineering Technology

Office of Nuclear Regulatory Research

U.S. Nuclear Regulatory Commission

Washington, DC 20555-0001

NRC Job Code Y6388

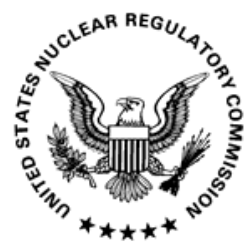




\section{Abstract}

As many pressurized water reactors (PWRs) age and life extension of the aged plants is considered, void swelling behavior of austenitic stainless steel (SS) core internals has become the subject of increasing attention. In this report, the available database on void swelling and density change of austenitic SSs was critically reviewed. Irradiation conditions, test procedures, and microstructural characteristics were carefully examined, and key factors that are important to determine the relevance of the database to PWR conditions were evaluated. Most swelling data were obtained from steels irradiated in fast breeder reactors at temperatures $>385^{\circ} \mathrm{C}$ and at dose rates that are orders of magnitude higher than PWR dose rates. Even for a given irradiation temperature and given steel, the integral effects of dose and dose rate on void swelling should not be separated. It is incorrect to extrapolate swelling data on the basis of "progressive compounded multiplication" of separate effects of factors such as dose, dose rate, temperature, steel composition, and fabrication procedure. Therefore, the fast reactor data should not be extrapolated to determine credible void swelling behavior for PWR end-of-life (EOL) or life-extension conditions.

Although the void swelling data extracted from fast reactor studies is extensive and conclusive, only limited amounts of swelling data and information have been obtained on microstructural characteristics from discharged PWR internals or steels irradiated at temperatures and at dose rates comparable to those of a PWR. Based on this relatively small amount of information, swelling in thin-walled tubes and baffle bolts in a PWR is not considered a concern. As additional data and relevant research becomes available, the newer results should be integrated with existing data, and the worthiness of this conclusion should continue to be scrutinized. PWR baffle reentrant corners are the most likely location to experience high swelling rates, and hence, high swelling at EOL, especially in internal regions of small volume where irradiation temperature is high. However, it is considered unlikely that void swelling in a reentrant corner will exceed the threshold level of $\approx 4 \%$ beyond which the swelling rate reaches the steady state rate of $1 \% / \mathrm{dpa}$. However, this estimation is only preliminary, and a more accurate quantification of maximum temperature of reentrant corners at EOL and life-extension situations would be useful. 



\section{Foreword}

This contractor-prepared NUREG-series report on void swelling is the first in a series of reports addressing irradiation effects on the internal structures of pressurized-water reactor vessels. Forthcoming NUREG-series reports will address irradiation embrittlement in cast and wrought stainless steels (SSs), as well as the development and application of models for predicting the effects of irradiation.

Void swelling results from the agglomeration of microscopically small voids (or vacancies) produced during neutron irradiation. The primary variables that control the degree of void swelling are temperature and neutron dose.

Research on irradiation degradation in liquid metal, fast breeder reactor (LMFBR) systems in the early 1980s produced an enormous quantity of data describing the kinetics and consequences of void swelling in SSs and nickel-base alloys proposed for use in those systems. The operational parameters of breeder reactor systems feature operating temperatures and neutron flux rates that are considerably higher than those that are characteristic of light-water reactors (LWRs). Extrapolation of the LMFBR data to LWR operational regimes is extremely tenuous, given the differences in energy spectra and temperature, leading to predictions of LWR materials degradation that range from "possibly significant" to "little, if any, effect."

Primarily through the Generic Aging Lessons Learned (GALL) program, the U.S. Nuclear Regulatory Commission established guidance that the issue of void swelling should be made a part of the vessel internals aging management program (AMP) for each licensee. As a result, the safety evaluation reports (SERs) issued by the agency in response to license renewal applications generally state that each licensee will make void swelling, and the other irradiation degradation issues, part of their AMP. The SERs also state that licensees should keep the agency informed "on a periodic basis" of progress in the evaluation of irradiation degradation issues.

This report contains critical reviews of several publications containing data that can be directly applied, or extrapolated with some confidence, to the operational characteristics of LWRs. As such, this review includes several relatively recent reports emanating from industry-funded programs. The conclusion is that void swelling is not likely to be an issue for either the initial term of a license or its extension period. Much additional research is currently underway, and the results should be carefully monitored for any indication to the contrary.

Carl J. Paperiello, Director

Office of Nuclear Regulatory Research

U.S. Nuclear Regulatory Commission 


\section{Contents}

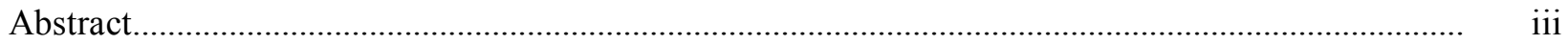

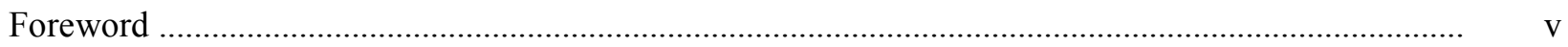

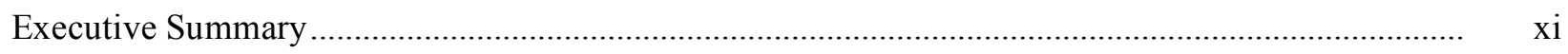

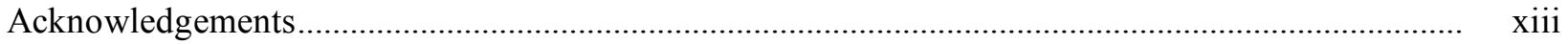

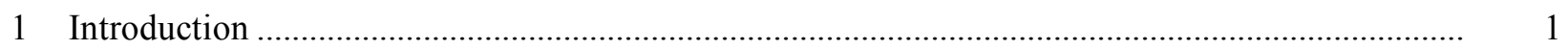

2 Void Swelling Data from PWR Components............................................................................ 3

2.1 Void Swelling in Ringhals PWR Flux Thimble Tube........................................................ 3

2.2 Void Swelling in PWR Lock Bars and Baffle Bolts .......................................................... 4

2.3 Void Swelling in a Tihange PWR Baffle Bolt ................................................................ 5

2.4 Void Swelling in Japanese PWR Flux Thimble Tubes ....................................................... 6

2.5 Void Swelling in a Westinghouse PWR Flux Thimble Tube …........................................ 6

2.6 Summary of Void Swelling Data from PWR Internals .....................................................

3 Important Factors Used to Extrapolate Swelling Data from Fast-Breeder to PWR Conditions..... 9

3.1 Component Most Susceptible to High Swelling ............................................................. 9

3.2 Maximum Irradiation Temperature ……........................................................................ 10

3.3 Swelling in EBR-II Components Irradiated at $\leq 380^{\circ} \mathrm{C}$ at Dose Rates Comparable to PWR Dose Rates .................................................................................................. 11

3.4 Swelling in Steels Irradiated at $305-335^{\circ} \mathrm{C}$ in BN-350 at Dose Rates Comparable to PWR Dose Rates ........................................................................................................ 13

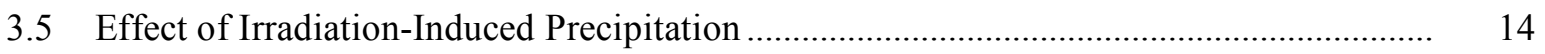

3.5.1 Low Swelling of CW Type 316 SS and High-Density Precipitation of $\gamma^{\prime}$ and an Unidentified Phase in PWR Baffle Bolts ........................................................ 16

3.5.2 Low Swelling in 348 SS and Dense Precipitation of NbC in a PWR .................. 16

3.5.3 Low Swelling and Dense Precipitates in SA Type 304 Irradiated to 50 dpa at $370^{\circ} \mathrm{C}$ in EBR-II at Dose Rate Relevant to PWR Reentrant Corner.

3.5.4 Low Density Change and High-Density Precipitation in CW Type 316 SS Irradiated to $23-51 \mathrm{dpa}$ at $375-430^{\circ} \mathrm{C}$ in EBR-II at Dose Rate Relevant to PWR Reentrant Corner.

3.5.5 Low Swelling and High-Density Precipitation of $\mathrm{G}$ Phase and $\mathrm{TiC}$ in $\mathrm{X} 18 \mathrm{H} 10 \mathrm{~T}$ SS Irradiated in $\mathrm{BN}-350$ at $305-355^{\circ} \mathrm{C}$ at Dose Rates Relevant to PWRs 


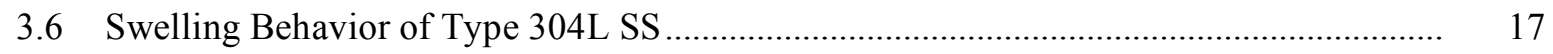

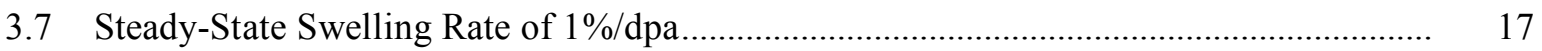

3.8 Threshold Swelling to Enter the Regime of Steady-State Swelling Rate .......................... 18

4 Assessment of the Potential for Void Swelling for PWR Internals at EOL …................................ 19

4.1 Thin-Walled Flux Thimble and Instrument Tubes ............................................................ 19

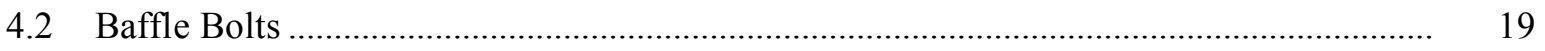

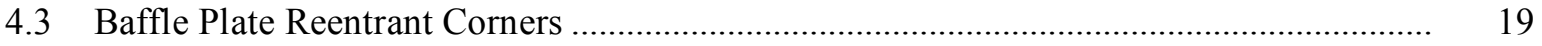

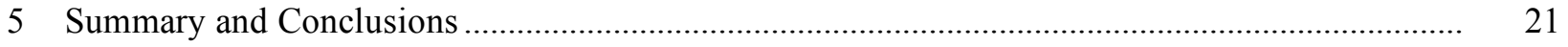

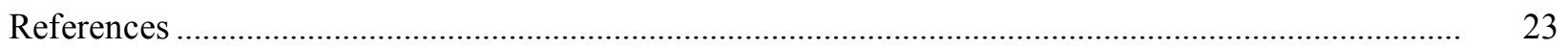


1. Range of irradiation temperature and dose for which void swelling data have been reported for PWR core internals.

2. Void swelling of PWR internals plotted as a function of dose.

3. Example of estimation of EOL void swelling reported by Garner for solution-annealed Type 304 SS reentrant corners.

4. Density change in CW Type 316 SS fuel hex can irradiated in reflector region of EBR-II at $376-460^{\circ} \mathrm{C}$ to $5-80 \mathrm{dpa}$.

5. Microstructure of SA Type $304 \mathrm{SS}$ fuel subassembly hex can irradiated in EBR-II at $370^{\circ} \mathrm{C}$ to $50 \mathrm{dpa}$.

6. Void swelling in Ti-containing Russian steel after $5.3 \mathrm{y}$ in $\mathrm{BN}-350$ breeder at $311-313^{\circ} \mathrm{C} \ldots \ldots \ldots . .$.

7. Schematic illustration of characteristics of irradiation-induced precipitation sensitive to dose rate and irradiation temperature.

8. Schematic illustration of three types of relationship between irradiation-induced precipitation and void swelling as a function of irradiation dose.

9. Low void swelling and high-density precipitation of $\gamma^{\prime}$ phase and unknown phase in the Tihange PWR baffle bolt fabricated from CW Type 316 SS. 


\section{Tables}

1. Void swelling in Ringhals-II PWR flux thimble tube after 23 years in service............................. 4

2. Void swelling data from industry PWR Baffle Bolt Project, quoted in MRP-50........................ 5

3. Void swelling data obtained from Japanese PWR flux thimble tubes. ........................................... 6

4. Void swelling data obtained from Westinghouse PWR flux thimble tubes.................................... 7 


\section{Executive Summary}

As many pressurized water reactors (PWRs) age and life extension of the aged plants is considered, void swelling behavior of austenitic stainless steel (SS) core internals has become the subject of increasing attention. In this report, the available database on void swelling and density change of austenitic SSs was critically reviewed. Irradiation conditions, test procedures, and microstructural characteristics were carefully examined, and key factors that are important to determine the relevance of the database to PWR conditions were evaluated.

Most swelling data that are available were obtained from steels irradiated in fast breeder reactors at temperatures $>385^{\circ} \mathrm{C}$ and at dose rates that are orders of magnitude higher than PWR dose rates. Extreme care must be exercised when interpreting and extrapolating such data. These data cannot be extrapolated to determine credible void swelling behavior for PWR end-of-life (EOL) or life-extension conditions. Even for a given irradiation temperature and given steel, the integral effects of dose and dose rate on void swelling cannot be separated. It is incorrect to extrapolate swelling data on the basis of "progressive compounded multiplication" of separate effects of factors such as dose, dose rate, temperature, and material composition.

Limited swelling data are available for cold-worked (CW) Type 316 SS irradiated to 53 dpa at 376$386^{\circ} \mathrm{C}$ and for solution-annealed (SA) Type $304 \mathrm{SS}$ irradiated to 50 dpa at $\approx 370^{\circ} \mathrm{C}$ in EBR-II reflector positions at dose rates comparable to those of PWR reentrant corners. As such, these data are relevant to the conditions of PWR reentrant corners. Swelling in these materials was less than $1 \%$.

The low void swelling observed in PWR components and in EBR-II steels under PWR-relevant dose rates appears to be associated with irradiation-induced formation of very fine precipitates (such as $G$ phase, carbides, and $\gamma^{\prime}$ phase) in high number density. Such irradiation-induced precipitation at low temperatures $\left(<370^{\circ} \mathrm{C}\right)$ creates an extremely large internal surface, i.e., the interface between the steel matrix and the precipitates. This interface acts as an efficient sink to irradiation-induced vacancies, thereby suppressing the agglomeration of the vacancies. Irradiation-induced precipitation is sensitive to minor alloying and impurity elements, irradiation temperature, and dose rate.

In thin-walled flux thimbles and instrument tubes, the effect of gamma heating is insignificant. The currently available database is sufficient to conclude that void swelling in this type of reactor internal, mostly fabricated from CW Type $316 \mathrm{SS}$, is not an issue.

Most PWR baffle bolts are fabricated from CW Type 316 SS. The data obtained from the industry baffle bolt program show that swelling is insignificant $(<0.25 \%)$ for dose levels up to $\approx 20 \mathrm{dpa}$ and irradiation temperatures of up to $\approx 340^{\circ} \mathrm{C}$. Data obtained on EBR-II components irradiated at temperatures $<380^{\circ} \mathrm{C}$ and at comparable dose rates are consistent with the data from the industry bolt program. Microstructural characteristics of the two groups of materials are also consistent. Thus, it is not likely that void swelling in this type of reactor internal will exceed the threshold level (i.e., $\approx 4 \%$ ) that is necessary to enter the regime of the steady-state swelling rate of $1 \% / \mathrm{dpa}$.

Most baffle reentrant corners are fabricated from SA Type 304 SS and are most susceptible to high swelling rates, and hence, high swelling at EOL. The maximum irradiation temperature in some regions of the reentrant corners has been estimated to be in the range of $\approx 380-420^{\circ} \mathrm{C}$. Only one investigation has reported void swelling for this class of steel after irradiation in EBR-II at $370^{\circ} \mathrm{C}$ to $\approx 50 \mathrm{dpa}$ at a dose rate comparable to that of reentrant corners. Void swelling in this material was only $0.54 \%$. The low swelling 
appears to be related to high-density irradiation-induced precipitation of very fine carbides. Therefore, it is considered unlikely that void swelling in reentrant corners will exceed the threshold level of $\approx 4 \%$. As a consequence, the potential impact of void swelling on core flow and the structural functions of the PWR internals is believed to be negligible.

However, this estimation is only preliminary. More relevant swelling data, including the effects of dose rate and temperature would be extremely helpful. Analyses to compute more accurate quantification of maximum temperature at EOL and life-extension situations are needed for SA Type 304 and Type 316 SSs. A better mechanistic understanding of the roles of irradiation-induced microstructural evolution on void swelling is also needed. Several experimental programs to address these issues are underway, and are expected to produce useful data in the next few years. 


\section{Acknowledgements}

The author thanks W. J. Shack, W. H. Cullen, Jr., and A. D. Lee for helpful comments. 


\section{Introduction}

As many pressurized water reactors (PWRs) age and life extension of the aged plants is considered, void swelling behavior of austenitic stainless steel (SS) core internals has become the subject of increasing attention. Excessive void swelling can lead to dimensional instability of the component and significant degradation of fracture toughness. It could also influence or contribute to the susceptibility of the component to irradiation-assisted stress corrosion cracking (IASCC), stress relaxation, or irradiation embrittlement.

Because of experimental problems largely related to the salvaging and handling of large, highly irradiated reactor components, it is either very difficult or impractical to obtain directly applicable void swelling data from actual PWR internals that have reached an end-of-life (EOL) condition. Therefore, a method commonly used to infer such information is to extrapolate more abundant data obtained under liquid metal, fast breeder reactor (LMFBR) conditions to PWR EOL or life-extension conditions. Many uncertainties are involved in this process, and the outcome of such extrapolation is often considered either unconvincing or questionable.

Compared to LMFBRs, the neutrons resulting from the fission process in light water reactors (LWRs) are moderated and slowed, or "thermalized", resulting in a higher probability of their capture by surrounding materials. As these thermal neutrons bombard the structural materials that support the fuel and reactor core components, the atoms of the material, are displaced, often much more than just once, resulting in the production of large numbers of vacancies and interstitials, with important consequences on strength and resistance to failure of these materials. Simultaneous with the bombardment and consequent damage, the moderately high temperatures of the core internal materials $\left[\sim 338^{\circ} \mathrm{C}\left(\sim 640^{\circ} \mathrm{F}\right)\right]$ produce an offsetting process of annealing and consolidation of the radiation damage into voids, dislocation loops and other microscopically faulted structures. ${ }^{*}$ In addition, many of the point defects formed through neutron bombardment simply diffuse to sinks of various types, including external surfaces, grain boundaries, or interphase surfaces. If the temperatures are high (around $400^{\circ}$ to $560^{\circ} \mathrm{C}$ ) and the irradiation damage extensive $\left(>10^{23} \mathrm{n} / \mathrm{cm}^{2}, \mathrm{E}>0.1 \mathrm{MeV}\right)$, the voids that are formed could conceivably produce dimensional changes, resulting in misfitting of the components, increases in stress, and other unacceptable consequences.

The data from investigations related to LMFBR performance shows the void swelling process is divided into two phases - an incubation period, followed by a period of void formation. Once voids have started to form, a general rule of thumb is that swelling proceeds at a rate of $1 \%$ per dpa accumulated. However, the incubation period is influenced by a number of important variables, including cold work, which tends to extend the period of incubation, and metal chemistry, which can either extend or foreshorten the incubation period. Because cold work extends the onset of swelling, core baffle bolts are frequently fabricated from $20 \%$ cold-worked (CW), Type $316 \mathrm{SS}$. There are many other considerations to the topic of void swelling, and the reader is referred to Ref. 1 - an excellent review of irradiation damage, albeit from a LMFBR point of view.

\footnotetext{
Neutrons can also cause transmutation of some of the lighter elements such as boron, generally found in trace amounts in structural materials. However, the amounts of helium and possibly hydrogen that are produced by transmutation of light elements is not likely to contribute significantly to void formation. Thermal neutron bombardment of nickel can produce a few parts per million amounts of helium during the course of a reactor lifetime, which could contribute to void production.
} 
The relatively high operating temperatures and much higher (but less thermalized) neutron fluxes that characterize fast reactors enable relatively easy detection of void formation in many core component materials, especially solution-annealed (SA) and CW 300-series SSs. At issue has been whether voids would form and become problematic under the less favorable LWR operational characteristics. The objective of this report is to critically review the applicable database and independently assess void swelling in austenitic SS PWR core internals. 


\section{Void Swelling Data from PWR Components}

In this section, void swelling data obtained from discharged PWR core internals are reviewed. At this time, such data are rather limited except for results obtained on flux thimble tubes.

\subsection{Void Swelling in Ringhals PWR Flux Thimble Tube (Ref. 2)}

The Electric Power Research Institute (EPRI) project (Project Manager, H. T. Tang) for this investigation $^{2}$ was cosponsored by the industry International Irradiation-Assisted Stress Corrosion Cracking Advisory Committee (Chairman, T. Mager, Westinghouse), and the report was authored by Westinghouse (J. Conermann and R. Shogan) and Japanese PWR (JPWR) investigators (S. Yamaguchi, H. Kanasaki, S. Nashida, K. Fujimoto, Y. Tamaguchi, and T. Yonezawa).

Several types of tests under PWR conditions were performed on small specimens obtained from a flux thimble tube after $23 \mathrm{y}$ of service in the Ringhals PWR (in Sweden), i.e., microstructural characterization by transmission electron microscopy (TEM), stress corrosion crack initiation in O-ring specimens, slow-strain-rate tensile tests in PWR water, and tensile tests in an inert environment.

The flux thimble tube was fabricated from Type 316 SS (composition in wt.\%: C 0.045, Si 0.43, Mn 2.69, P 0.026, S 0.01, Ni 13.3, Cr 17.4, and Mo 2.69). The Mn content of the heat is somewhat higher than the normal AISI specification limit of $2.0 \mathrm{wt} . \%$. The thimble was $10-12 \% \mathrm{CW}$ after final anneal, producing a yield strength of $480-620 \mathrm{MPa}$ and an ultimate tensile strength of $>690 \mathrm{MPa}$.

The position of the thimble tube was near the center of the core. Depending on the axial level, the estimated irradiation temperature and neutron damage of the specimen blanks ranged, respectively, from 290 to $325^{\circ} \mathrm{C}$ and from 17 to $65 \mathrm{dpa}$. Because all specimen blanks were in service for the same period of time of $23 \mathrm{y}$, the dose rate of each blank varied, that is, a lower dose rate for a 17-dpa blank and 3.8 times higher dose rate for a 65 -dpa blank.

Microstructural characterization was performed on three blanks at the Nuclear Development Company (NDC) in Japan. Thin foils were characterized with a field-emission-gun transmission electron microscope (FEG-TEM), Model JEOL JEM-2010F. Microcavities and voids were imaged in bright field at magnifications of 500,000 and 1,000,000 times by the through-focus technique (over-focus, in-focus, and under-focus). The size of most voids was in the range of 1-2 nm, but spherically shaped microcavities as large as $\approx 6 \mathrm{~nm}$ in diameter were also observed.

It is customary to independently measure density change of irradiated specimens in parallel with void characterization. However, the swelling data were not confirmed by this technique.

Determination of the degree of swelling was based on the average size and number density of the voids that were imaged in the bright field. In this process, the thickness of the imaged thin foil region was accounted for. The results, obtained for three samples, are summarized in Table 1.

The void number was counted by a computerized method. Bright-field high-magnification images of an examined region that contained thousands of voids were scanned into a computer, and the number of voids was determined with an image-processing software. This method is fairly accurate. 
Table 1. Void swelling in Ringhals-II PWR flux thimble tube (CW Type 316 SS) after 23 y in service (from MRP-73, Ref. 2).

\begin{tabular}{|c|c|c|c|c|c|c|}
\hline $\begin{array}{c}\text { Sample } \\
\text { ID }\end{array}$ & $\begin{array}{c}\text { Irradiation } \\
\text { Temp. } \\
\left({ }^{\circ} \mathrm{C}\right)\end{array}$ & $\begin{array}{c}\text { Neutron } \\
\text { Damage } \\
(\mathrm{dpa})\end{array}$ & $\begin{array}{c}\text { Average } \\
\text { Void Size } \\
(\mathrm{nm})\end{array}$ & $\begin{array}{c}\text { Total } \\
\text { Void } \\
\text { Number }\end{array}$ & $\begin{array}{c}\text { Imaged } \\
\text { Volume } \\
\left(10^{6} \mathrm{~nm}^{3}\right)\end{array}$ & $\begin{array}{c}\text { Swelling } \\
(\%)\end{array}$ \\
\hline $\mathrm{A}$ & 320 & 65 & 1.20 & 2969 & 9.14 & 0.0294 \\
\hline $\mathrm{B}$ & 295 & 61 & 1.24 & 2130 & 8.14 & 0.0270 \\
\hline $\mathrm{E}$ & 325 & 17 & 1.34 & 829 & 7.57 & 0.0140 \\
\hline
\end{tabular}

Uncertainty in the thickness of the examined region of the thin foil could lead to some degree of uncertainty in the reported degree of void swelling. However, typical uncertainty in foil thickness is no more than a factor of two, which means that void swelling should be no more than $\approx 0.06 \%$.

The electron-transparent region of the thin film was prepared by electrochemical jet polishing with a methanol-water solution that contained 5 vol.\% perchloric acid. In this type of method, artifact surface hydrides and oxides of microscopic size could be produced, depending on material type and jet-polishing temperature. If such artifacts were produced, the net effect would be somewhat less void swelling than the measured value. However, such an effect is not significant for austenitic SSs.

Besides twins and the customary black-dot defects, the investigators did not characterize irradiation-induced precipitates, which would require difficult dark-field and tilting analysis. Therefore, it is not clear if voids and cavities were the only significant microstructural features.

However, the study provides a valuable database which shows that void swelling at $290-325^{\circ} \mathrm{C}$ at $\leq 65$ dpa was insignificant in the CW Type 316 SS flux thimble tube after 23 y of service in the Ringhals PWR.

\subsection{Void Swelling in PWR Lock Bars and Baffle Bolts (Ref. 3)}

The EPRI interim report (Project Manager, H. T. Tang) was authored by U.S. industry investigators (S. Byrne and I. Wilson, Westinghouse and S. Fyfitch and H. Xu, Framatome) and F. A. Garner of Pacific Northwest National Laboratory (PNNL). ${ }^{3}$ The sections on void swelling in the report seem to heavily reflect the view of the latter investigator who has extensive experience in void swelling in steels irradiated in a fast breeder reactor or under fusion reactor conditions. The report provides a comprehensive assessment of void swelling data obtained under such accelerating conditions, and of the effects of separate factors such as irradiation temperature, dose rate, dose, neutron spectrum, impurities, cold work, annealing, and irradiation creep.

However, the report provides only very limited information on void swelling in PWR internals. The data, summarized in Table 2, are based on two earlier reports. ${ }^{4,5}$ Void swelling data in the latter document appear to be from the results of a transmission electron microscopy (TEM) investigation conducted by Thomas and Bruemmer and documented in Ref. 6 . The results of this investigation, performed on a Tihange PWR baffle bolt, will be reviewed separately below.

The data summarized in Table 1 (flux thimble) and Table 2 (baffle bolt) are essentially consistent, in that void swelling in the examined PWR components was insignificant. Void swelling of $0.20-0.24 \%$ was observed in the local regions of bolt $2 \mathrm{~K} 1 \mathrm{R} 5$, which had been exposed to somewhat higher 
Table 2. Void swelling data from industry PWR Baffle Bolt Project, quoted in MRP-50, (Ref. 3).

\begin{tabular}{|c|c|c|c|c|c|}
\hline $\begin{array}{l}\text { Bar or } \\
\text { Bolt ID }\end{array}$ & $\begin{array}{l}\text { Specimen } \\
\text { Location }\end{array}$ & $\begin{array}{l}\text { Steel } \\
\text { Type }\end{array}$ & $\begin{array}{l}\text { Irradiation } \\
\text { Temp. }\left({ }^{\circ} \mathrm{C}\right)\end{array}$ & $\begin{array}{c}\text { Neutron } \\
\text { Damage (dpa) }\end{array}$ & $\begin{array}{c}\text { Swelling } \\
(\%)\end{array}$ \\
\hline G130 & Lock bar & SA 304 & 290 & 20.7 & 0.0 \\
\hline 3324 & Lock bar & SA 304 & 290 & 25 & 0.0 \\
\hline 2322 & Lock bar & SA 304 & 290 & 24 & 0.0 \\
\hline 2K1R5 & Bolt head & CW 316 & 320 & 19.5 & Visible voids \\
\hline 2K1R5 & Bolt shank & CW 316 & 343 & 12.2 & 0.20 \\
\hline 2K1R5 & $\begin{array}{c}\text { Near bolt } \\
\text { threads }\end{array}$ & CW 316 & 330 & 7.5 & 0.24 \\
\hline G96B & $\begin{array}{l}\text { Near bolt } \\
\text { threads }\end{array}$ & CW 316 & 329 & 9.2 & 0.011 \\
\hline G96B & Bolt head & CW 316 & 290 & 18.4 & 0.0 \\
\hline 4522 & $\begin{array}{l}\text { Near bolt } \\
\text { threads }\end{array}$ & SA 347 & 329 & 8.6 & 0.029 \\
\hline 4522 & Bolt head & SA 347 & 290 & 16.4 & 0.0 \\
\hline 4116 & Bolt head & SA 347 & 290 & 14.1 & 0.0 \\
\hline 2322 & $\begin{array}{l}\text { Near bolt } \\
\text { threads }\end{array}$ & SA 347 & 329 & 11 & 0.004 \\
\hline 2322 & Bolt head & SA 347 & 329 & 20 & 0.0 \\
\hline
\end{tabular}

temperatures, i.e., $330-343^{\circ} \mathrm{C}$ vs. $<329^{\circ} \mathrm{C}$. For bolt 4522 , the data indicate a slightly higher swelling $(0.029$ vs. $0.0 \%)$ at higher temperature $\left(329\right.$ vs. $\left.290^{\circ} \mathrm{C}\right)$. However, a definite trend of temperature dependence is not observed.

\subsection{Void Swelling in a Tihange PWR Baffle Bolt (Refs. 3, 6, and 7)}

The primary focus of the report in Ref. 3 (EPRI-1003422) is FEG-TEM characterization of grainboundary crack-tip microstructure and microchemistry of a field-cracked Oyster Creek boiling water reactor (BWR) top guide and a Tihange PWR baffle bolt. Several high-quality photomicrographs shown in the report provide information on void swelling in the baffle bolt material (Bolt ID 2K1R, Specimen ID 2K1R1, from the bolt shank, CW Type 316 SS, see Table 2). In Figs. 3-5 (a) and (b) of the report, two types of spherical voids are shown, one $4-6 \mathrm{~nm}$ in diameter; the other, $<1 \mathrm{~nm}$. This observation is consistent with the results of the NDC characterization of voids in the Ringhals flux thimble irradiated to 61-65 dpa (see Section 2.1 above).

As listed in Table 2, void swelling in the Tihange bolt $2 \mathrm{~K} 1 \mathrm{R}$ was $\approx 0.2 \%$ at $7.5-12.2 \mathrm{dpa}$. Reference 7 by Garner et al. 2001, presents FEG-TEM photomicrographs that show the morphology and distribution of voids at three locations of the same bolt: head $\left(1 \mathrm{~mm}\right.$ from the head surface, $320^{\circ} \mathrm{C}$, $19.5 \mathrm{dpa}$, seven voids visible), shank ( $25 \mathrm{~mm}$ from the head surface, $343^{\circ} \mathrm{C}, 12.2 \mathrm{dpa}, 0.20 \% \mathrm{swelling}$ ), and near the bolt threads $\left(55 \mathrm{~mm}\right.$ from the head surface, $333^{\circ} \mathrm{C}, 7.5 \mathrm{dpa}, 0.24 \%$ swelling). 


\subsection{Void Swelling in Japanese PWR Flux Thimble Tubes (Ref. 8)}

This joint project $^{8}$ was conducted by investigators of the Japan Institute of Nuclear Safety System, Inc., Nippon Nuclear Fuel Development Co., and Kyoto University. Microstructural characterization was performed with a Hitachi HF-2000 FEG-TEM.

Two flux thimble tubes were irradiated in a JPWR during service for 9 and 13 effective full power years (EFPY). The estimated neutron damage and irradiation temperature, respectively, are 35 dpa and $310^{\circ} \mathrm{C}$ for the former (9 EFPY) tube and $1-53$ dpa at $290-320^{\circ} \mathrm{C}$ for the latter tube. Both tubes were fabricated from a $15 \%-\mathrm{CW}$ heat of Type $316 \mathrm{SS}$ that contained (in wt.\%) $0.040 \mathrm{C}, 0.62 \mathrm{Si}, 1.63 \mathrm{Mn}$, $0.22 \mathrm{P}, 0.006 \mathrm{~S}, 12.6 \mathrm{Ni}, 16.94 \mathrm{Cr}$, and 2.22 Mo.

The shape of the examined region of the thin foil and the distribution of voids were determined by the technique of stereomicroscopy as a function of foil thickness. Stereomicroscopy of voids or precipitates as small as $\approx 1 \mathrm{~nm}$ is very difficult and painstaking work. Size distribution of voids was also determined. Most voids were $<1.4 \mathrm{~nm}$, and only a limited number of voids $>2 \mathrm{~nm}$ was observed. The overall quality of the FEG-TEM work appears to be excellent, and the information on the spatial and size distributions of the voids provides additional confidence in the quality of swelling data.

Table 3 summarizes the results of FEG-TEM characterization of void size, distribution, and swelling percent. The results, consistent with the swelling behavior of the Ringhals flux thimble tube and Tihange baffle bolt, showed that swelling was only $<0.042 \%$ and that there was no clear dependence on dose in the range of 1-53 dpa. The latter is probably because swelling was so low.

Table 3. Void swelling data obtained from Japanese PWR flux thimble tubes (CW Type 316 SS), from Fujii et al. 2001 (Ref. 8).

\begin{tabular}{|c|c|c|c|c|c|}
\hline $\begin{array}{c}\text { Dose } \\
(\mathrm{dpa})\end{array}$ & $\begin{array}{c}\text { Dose rate } \\
\left(10^{-9} \mathrm{dpa} / \mathrm{s}\right)\end{array}$ & $\begin{array}{c}\text { Irradiation } \\
\text { Temperature } \\
\left({ }^{\circ} \mathrm{C}\right)\end{array}$ & $\begin{array}{c}\text { Void Average } \\
\text { Diameter } \\
(\mathrm{nm})\end{array}$ & $\begin{array}{c}\text { Void Number } \\
\text { Density } \\
\left(10^{23} \mathrm{~m}^{-3}\right)\end{array}$ & $\begin{array}{c}\text { Void } \\
\text { Swelling } \\
(\%)\end{array}$ \\
\hline 1 & 2 & 290 & $($ No void $)$ & 0.0 & 0.0 \\
\hline 3 & 8 & 290 & 0.94 & 3.6 & 0.015 \\
\hline 10 & 26 & 320 & 0.92 & 5.0 & 0.020 \\
\hline 28 & 69 & 320 & 0.95 & 9.4 & 0.042 \\
\hline 31 & 76 & 290 & 1.01 & 6.9 & 0.038 \\
\hline 33 & 82 & 320 & 1.04 & 3.1 & 0.018 \\
\hline 53 & 130 & 300 & 1.05 & 5.8 & 0.036 \\
\hline 35 & 110 & 310 & 0.94 & 3.8 & 0.016 \\
\hline 35 & 110 & 310 & 0.96 & 4.2 & 0.020 \\
\hline 35 & 110 & 310 & 0.98 & 3.8 & 0.019 \\
\hline
\end{tabular}

\subsection{Void Swelling in a Westinghouse PWR Flux Thimble Tube (Ref. 9)}

In this earlier work by Westinghouse investigators, ${ }^{9}$ two flux thimble tubes were examined after 11 EFPY of service in a PWR. The tubes were fabricated from CW Type 316 SS that contained (in wt.\%) 0.044 C, 0.75 Si, 1.75 Mn, 0.014 P, 0.011 S, 13.10 Ni, 17.50 Cr, 2.64 Mo, and 0.040 Co. 
The irradiation at $305-315^{\circ} \mathrm{C}$ produced $\approx 35 \mathrm{dpa}$ and $208 \mathrm{appm} \mathrm{He}(\mathrm{He} / \mathrm{dpa}$ ratio $5.9 \mathrm{appm} / \mathrm{dpa})$. The procedure for specimen preparation was similar to that of the other studies above (electrochemical jet polishing at $-35^{\circ} \mathrm{C}$ in a solution of $20 \%$ perchloric acid and $80 \%$ methanol). Microstructural characterization was performed with a Phillips CM30 analytical TEM. Table 4 summarizes void swelling data from this investigation. The result is similar to results from the Ringhals and the JPWR flux thimble tubes.

Table 4. Void swelling data obtained from Westinghouse PWR flux thimble tubes (CW Type 316 SS), from Foster et al. (Ref. 9).

\begin{tabular}{|c|c|c|c|c|}
\hline $\begin{array}{c}\text { Dose } \\
(\mathrm{dpa})\end{array}$ & $\begin{array}{c}\text { Irradiation } \\
\text { Temp. }\left({ }^{\circ} \mathrm{C}\right)\end{array}$ & $\begin{array}{c}\text { Void Average } \\
\text { Diameter }(\mathrm{nm})\end{array}$ & $\begin{array}{c}\text { Void Number Density } \\
\left(10^{23} \mathrm{~m}^{-3}\right)\end{array}$ & $\begin{array}{c}\text { Swelling } \\
(\%)\end{array}$ \\
\hline 3 & 310 & $($ No void $)$ & 0 & 0 \\
\hline 35 & 310 & $\approx 1$ & 6 & 0.03 \\
\hline
\end{tabular}

\subsection{Summary of Void Swelling Data from PWR Internals}

The void swelling data listed in Tables $1-4$ are plotted in Fig. 1 as a function of dpa and irradiation temperature. Note that a higher level of swelling is denoted with a larger circle with a darker color. Figure 2 is a plot of void swelling of PWR internals as function of dose (dpa).

The maximum observed void swelling was $0.020-0.24 \%$ at $\approx 333-343^{\circ} \mathrm{C}$ at $7.5-12.2 \mathrm{dpa}$ for the flux thimble tube and baffle bolts fabricated from CW Type 316 SS. No swelling larger than $0.25 \%$ was observed. This level of swelling is insignificant.

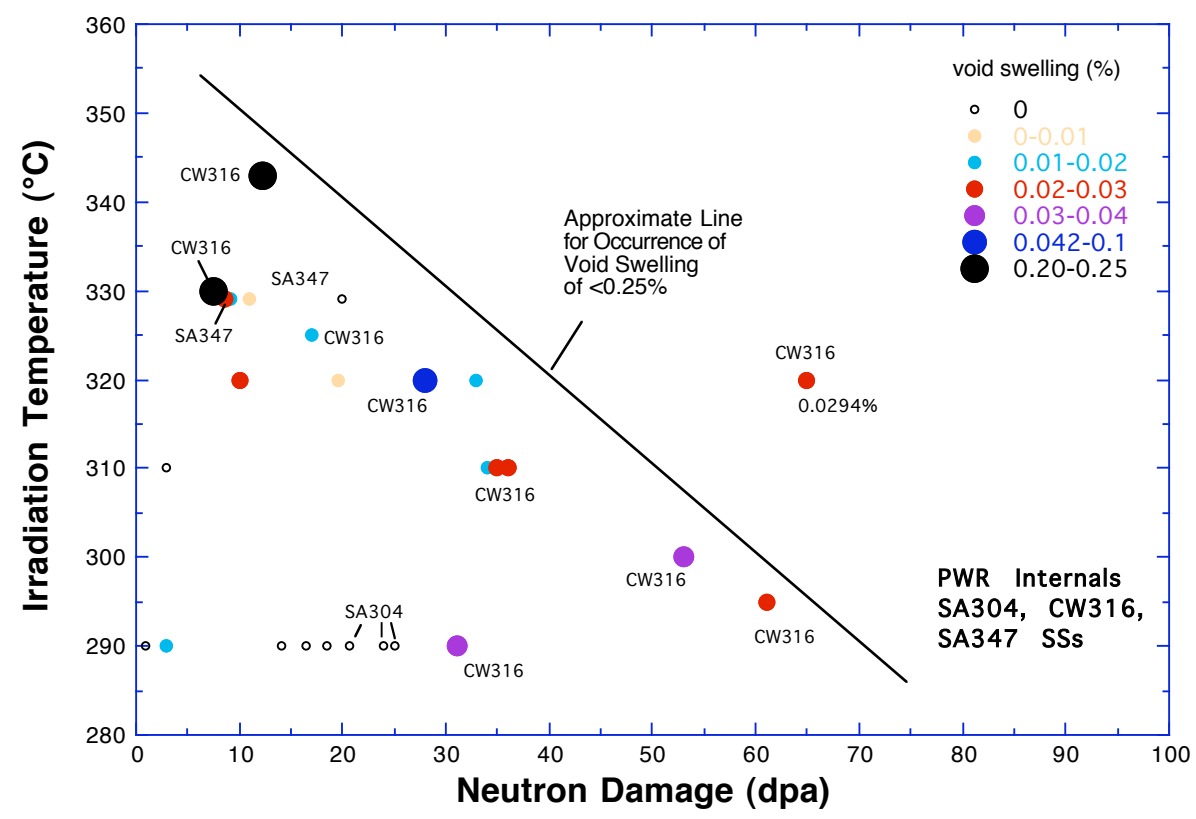

Figure 1. Range of irradiation temperature and dose for which void swelling data (in color code) have been reported for PWR core internals. 


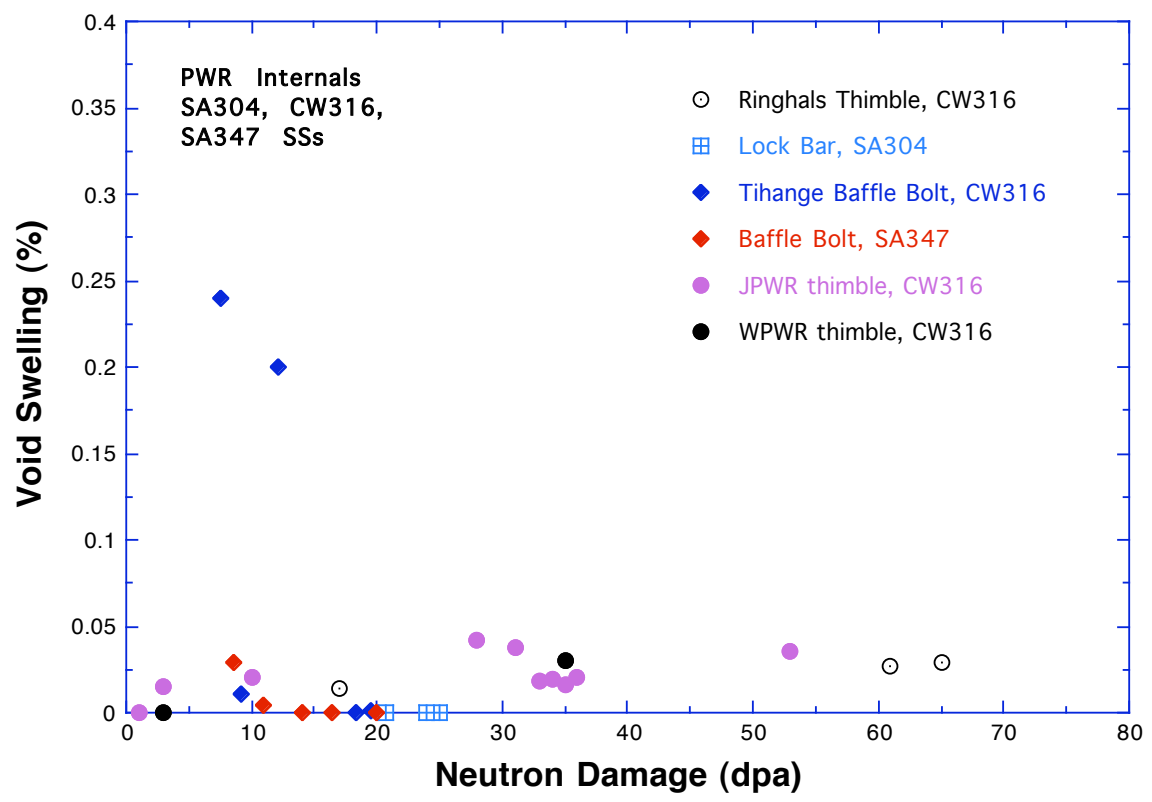

Figure 2. Void swelling of PWR internals plotted as a function of dose (dpa).

To show, approximately, the range of dpa-temperature in which void swelling of $<0.25 \%$ was observed, a trend line was drawn in the figure. Because the void swelling was so low and because the uncertainty limit associated with such low swelling is significantly large, it is not possible to extract a more quantitative correlation among swelling, dpa, and irradiation temperature.

One conclusion that can be made with reasonable confidence is that void swelling in PWR flux thimble tubes and in baffle bolts is not a concern. For baffle bolts, the primary concern is the susceptibility to IASCC rather than void swelling. At this time, however, there is no conclusive evidence that void swelling plays an important role in IASCC of PWR baffle bolts. 


\section{Important Factors Used to Extrapolate Swelling Data from Fast- Breeder to PWR Conditions}

Void swelling refers to the volume expansion of materials under neutron irradiations. Microscopic voids developed from vacancy coalescence give rise to this geometry instability, which is quantified by percent change in volume of the material. Void swelling occurs as a result of microstructural changes involving point defects migration to various sinks such as interface, grain boundaries, and dislocations. The interaction between interstitials and dislocations is generally believed to be stronger due to a relatively large strain field that surrounds interstitials. Therefore, a preferential interstitial flux exists towards dislocations. Because of this "bias" interstitial flow, the remaining vacancies cannot be annihilated by recombining with interstitials and result in void nucleation and growth. Fission products such as helium or hydrogen also play an important role in void swelling. By combining with these gas atoms, void nucleation is facilitated through reduction of surface energy of vacancy cluster. However, the fundamental driving force of void swelling remains to be the excess vacancy flux towards voids.

The most important parameters that can influence void swelling are temperature and accumulated dose; other parameters that can influence void swelling include dose rate, material microstructure, and stress. At a given temperature, an incubation period of void swelling is observed in the low dose regime. Beyond a critical dose, a dramatic increase in void swelling takes place and a steady-state linear dependence of void swelling with radiation dose is observed. At constant radiation dose, the temperature dependence of void swelling shows a peak at an intermediate temperature, ${ }^{10}$ characteristic peak temperature is typically around $0.3 \mathrm{~T}_{\mathrm{m}}$. For austenitic $\mathrm{SSs}$, a CW structure is more resistant to void swelling relative to a SA structure. ${ }^{11}$ Cold work extends the incubation period for void swelling and increases the critical dose for the steady-state linear void swelling.

The void swelling data from PWR components that were reviewed in Section 2 are limited in irradiation temperature $\left(\leq 343^{\circ} \mathrm{C}\right)$, dose $(\leq 65 \mathrm{dpa})$, or both. For some components, these limits do not pose a problem in evaluating void swelling at EOL, e.g., the Ringhals flux thimble tube which was in service for $23 \mathrm{y}$ at $295-325^{\circ} \mathrm{C}$ and exhibited $<0.03 \%$ swelling at $<65 \mathrm{dpa}$. This observation and similar results of Fujii et al., ${ }^{8}$ are sufficient to conclude that void swelling in a flux thimble tube is not a concern.

However, some core internals are exposed to more severe conditions, i.e., significantly higher dose at higher temperatures. These components (e.g., baffle plate reentrant corners) are thick-walled, and their service temperature is somewhat elevated because of gamma heating. According to Garner, baffle reentrant corners are exposed to the highest temperature and to the highest level of damage compared to the other components (baffle plate, bolt, or former) (see Fig. 3). Assessment of void swelling for such a component is possible only through extrapolation of data obtained under non-PWR conditions in which dose rate and irradiation temperature differ significantly. Such extrapolation is a formidable task, and requires great caution. This section describes our current understanding of the key factors and soundness of such an extrapolation.

\subsection{Component Most Susceptible to High Swelling}

Garner attempted to evaluate the swelling behavior of reentrant corners, the component considered most susceptible to high swelling, Fig. 3 shows a summary of his analysis. For 40-y operation, the

* Private communications Frank Garner to Bill Cullen, August 2005. 
estimated swelling is as large as 55\% (see Fig. 3d). Although this estimation is intended primarily to illustrate an approach and is based on conservative assumptions, the large difference between Garner's estimation for reentrant corners and the maximum swelling actually observed for other PWR components, i.e., $55 \%$ vs. $\leq 0.24 \%$, is striking, and indicative of the difficulties encountered in the extrapolation of LMFBR-related test parameters and methods to the LWR operating characteristics.

\subsection{Maximum Irradiation Temperature}

Irradiation temperature is probably the single most important factor that influences void swelling in an austenitic SS at EOL. The irradiation temperature in the reentrant corners in Fig. 3 was estimated to be as high as $420^{\circ} \mathrm{C}$, about $90-95^{\circ} \mathrm{C}$ higher than the PWR outlet coolant temperature. The increase is

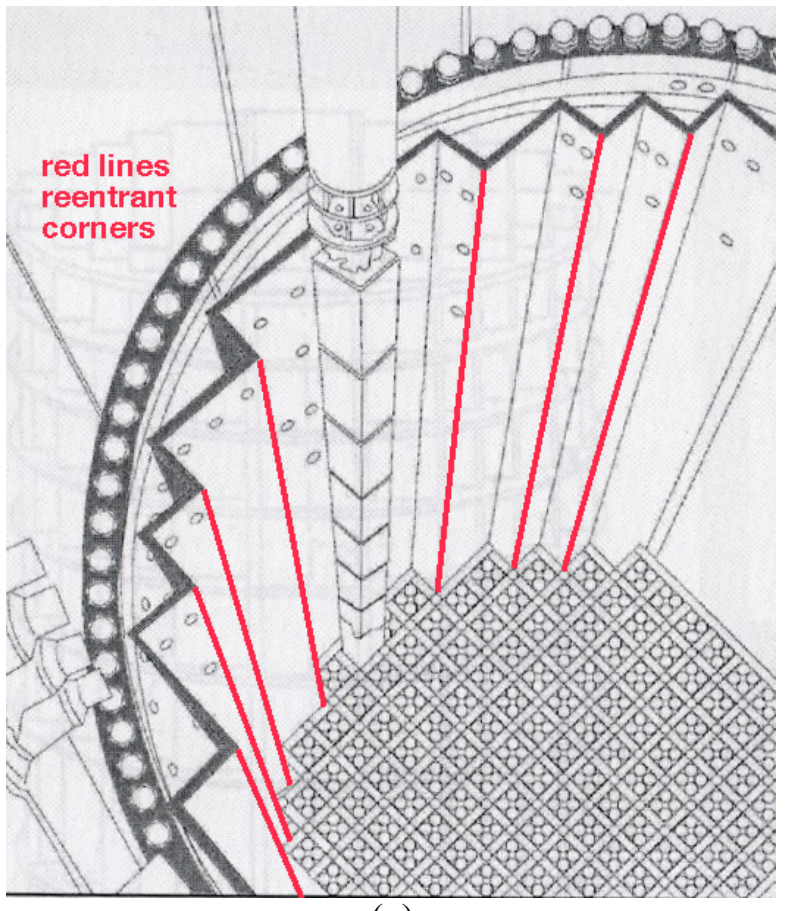

(a)

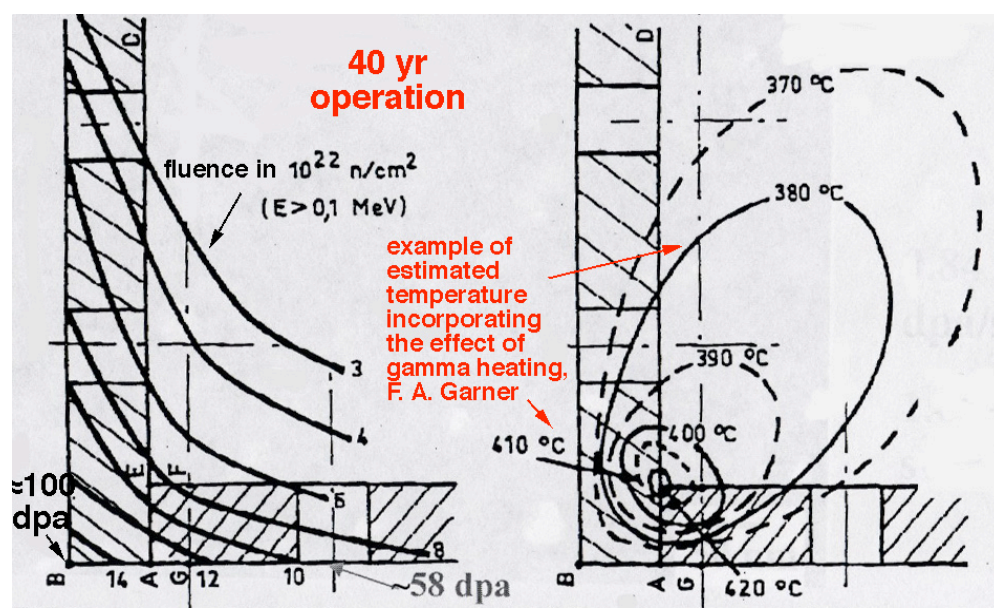

(c)

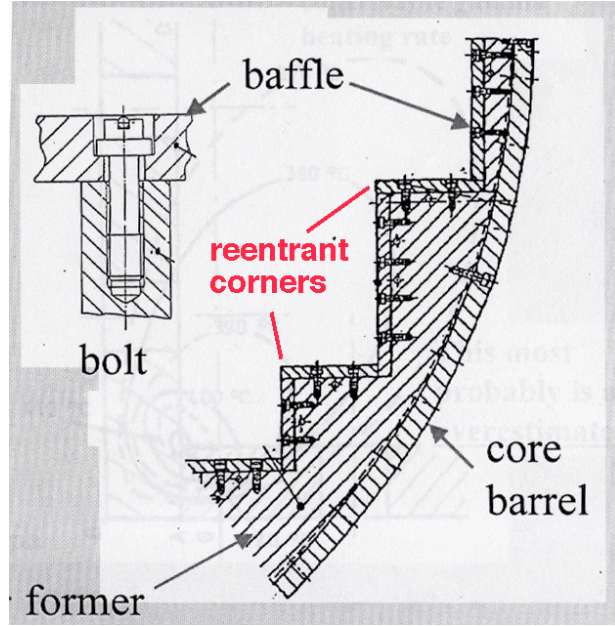

(b)

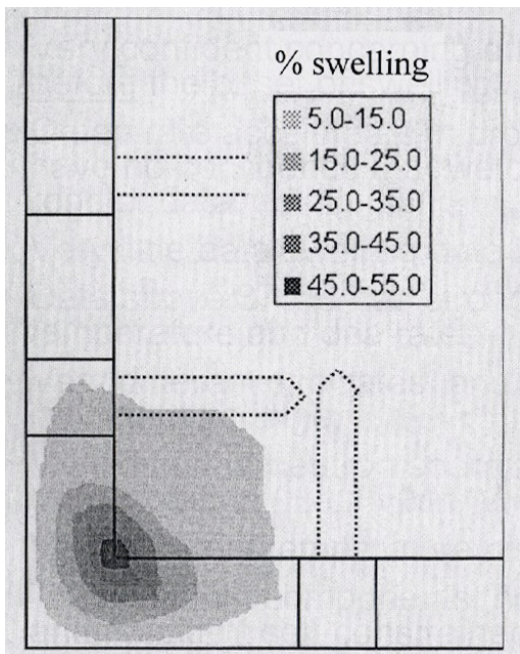

(d)

Figure 3. Example of estimation of EOL void swelling reported by Garner for solution-annealed Type 304 SS reentrant corners (see footnote previous page for Ref.). 
primarily due to gamma heating. The estimated value is probably too high. The maximum temperature in reentrant corners probably does not exceed $\approx 380^{\circ} \mathrm{C}$. For example, Allen et al. considered a maximum temperature of $\approx 370^{\circ} \mathrm{C}$ for PWR internals at a 40 -y EOL. 12

From the standpoint of void swelling that occurs over a long period of time (i.e., EOL or lifeextension situations), the difference in irradiation temperature (e.g., $420^{\circ} \mathrm{C}$ vs. $370^{\circ} \mathrm{C}$ ) is a crucial factor. Irradiation temperature of a reentrant corner is influenced by many factors such as: steel type; impurities in the steel; the source, energy, and the quantity of gamma-emitting radio nuclides; decay rate of the gamma source; thermal conductivity of the steel; oxide layer thickness on the surface of the reentrant corner; coolant temperature; fuel linear power generation rate; fuel burnup; axial location of the reentrant corner; and core axial power distribution. The linear power generation rate of the peripheral or corner rods in the peripheral fuel assembly strongly influences the temperature of the adjacent reentrant corner. These days, most PWRs operate with fuel burnup extended as high as $\approx 62 \mathrm{MWd} / \mathrm{kg} \mathrm{U}$. Because fuel liner power generation rate decreases significantly with increasing burnup, high-burnup operation is conducive to a lower irradiation temperature in a reentrant corner (than medium-burnup operation). Satisfactory quantification of the factors listed above, however, remains elusive. For a better understanding of void swelling behavior of reentrant corners under EOL or life-extension condition, accuracy in irradiation temperature is more important than any other factors, e.g., dose and dose rate.

\subsection{Swelling in EBR-II Components Irradiated at $\leq 380^{\circ} \mathrm{C}$ at Dose Rates Comparable to PWR Dose Rates}

Most of the data from steels irradiated in EBR-II were obtained for temperatures $>385^{\circ} \mathrm{C}$. However, some data have been reported by Allen et al. ${ }^{12}$ for CW Type $316 \mathrm{SS}$ at $376-386^{\circ} \mathrm{C}$ and by Chung et al. ${ }^{13}$ for SA Type $304 \mathrm{SS}$ at $370^{\circ} \mathrm{C}$. The data are shown in Fig. 4 . The steel specimens were obtained from fuel subassemblies (1-mm-thick hex can) located in the reflector region of the reactor. In that location, the steels are irradiated at lower temperatures, and their dose rates are about one order of magnitude lower than that in the fueled region. As such, the data are more relevant to the behavior of a PWR reentrant corner than the data obtained from steels irradiated at higher temperatures in the core center.

The CW Type 316 SS hex cans were fabricated from two heats, and the data in Fig. 4 reflect the effect of three dose rates that were a factor of $\approx 3$ apart. Figure 4 reveals: (a) a low but appreciable level of densification at low dpa, indicating the effect of irradiation-induced precipitation, (b) an insignificant effect of dose rate, (c) swelling at $376-386^{\circ} \mathrm{C}$ no greater than $0.8 \%$, and (d) the $1 \% /$ dpa steady-state swelling rate not reached even at $80 \mathrm{dpa}$ at $460^{\circ} \mathrm{C}$.

The distribution of voids and the microstructure of the hex can reported in Ref. $13(\approx 50$ dpa at $\approx 370^{\circ} \mathrm{C}$ ) are summarized in Fig. 5. Like a PWR reentrant corner, the hex can was fabricated from a SA Type $304 \mathrm{SS}$. At $\approx 50 \mathrm{dpa}$, the void swelling in the SA Type $304 \mathrm{SS}$ hex can (i.e., $0.54 \%$ ) agrees well with the density change in the $\mathrm{CW}$ Type $316 \mathrm{SS}$ hex can irradiated at $376-386^{\circ} \mathrm{C}$ (i.e., $\approx 0.8 \%$, Fig. 4).

Figure 3-3 of Ref. 3 shows a TEM photomicrograph of SA Type 304 SS irradiated in EBR-II to $21.7 \mathrm{dpa}$ at $380^{\circ} \mathrm{C}$. The figure, attributed to "unpublished micrograph of F. A. Garner," shows a void swelling of $\approx 2 \%$. This much swelling is significantly higher than that for $<386^{\circ} \mathrm{C}$ in Fig. 4 . It is not known if the steel was irradiated in the fueled region where the dose rate is orders of magnitude higher. The accuracy of the irradiation temperature is not known either. Also, the morphology (polygonal shape) and size $(\approx 20-60 \mathrm{~nm})$ of the voids in the micrograph differs somewhat from the morphology (spherical) 
and the size $(20-50 \mathrm{~nm})$ of the voids in Fig. 5 . The primary difference is the much higher void number density in the former material than in the latter.

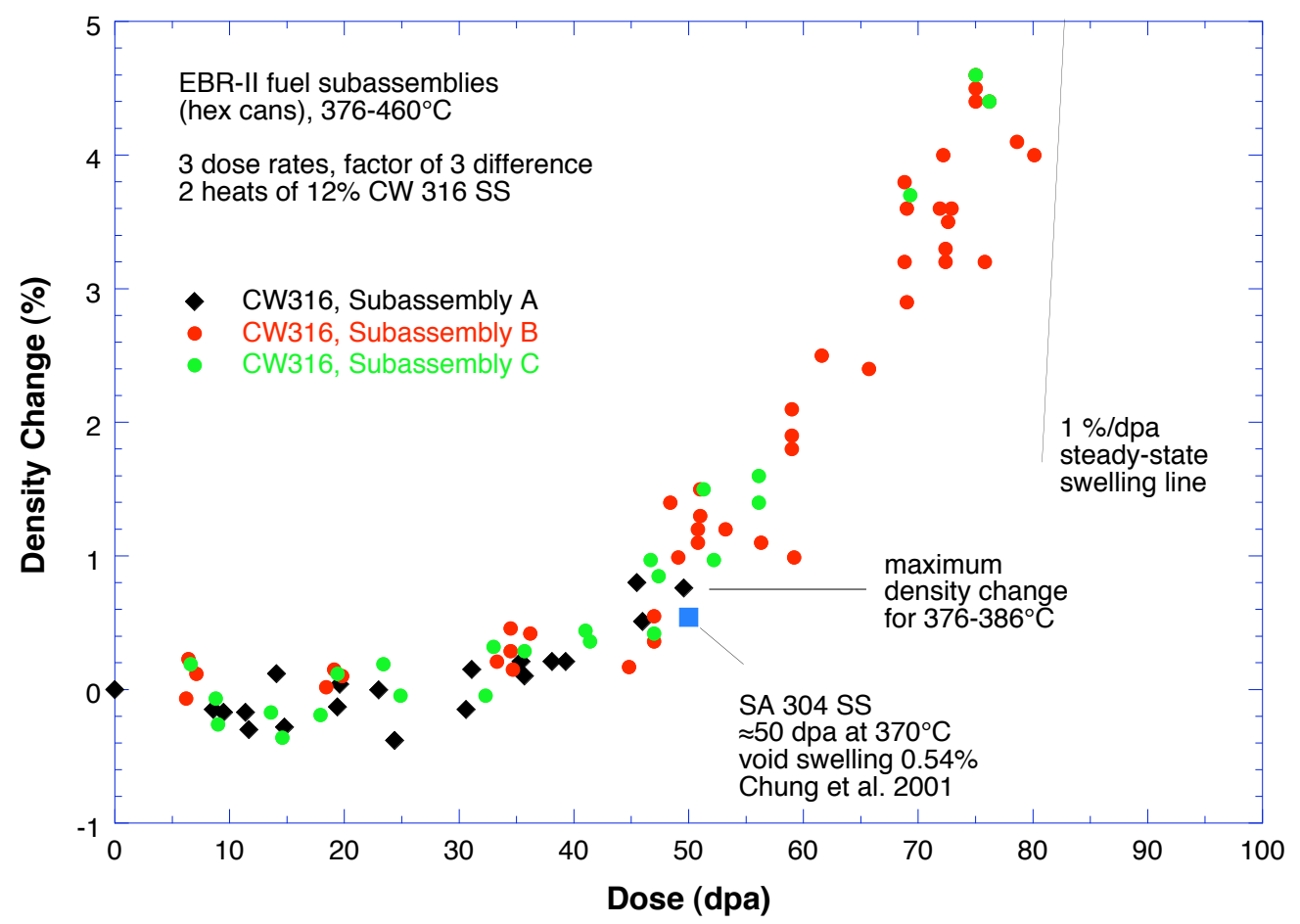

Figure 4. Density change in CW Type 316 SS fuel hex can irradiated in reflector region of EBR-II at $376-460^{\circ} \mathrm{C}$ to $5-80$ dpa (Ref. 8). Void swelling in a similar component fabricated from SA Type $304 \mathrm{SS}$ is shown for comparison (from TEM analysis of Ref. 13; see Fig. 12).

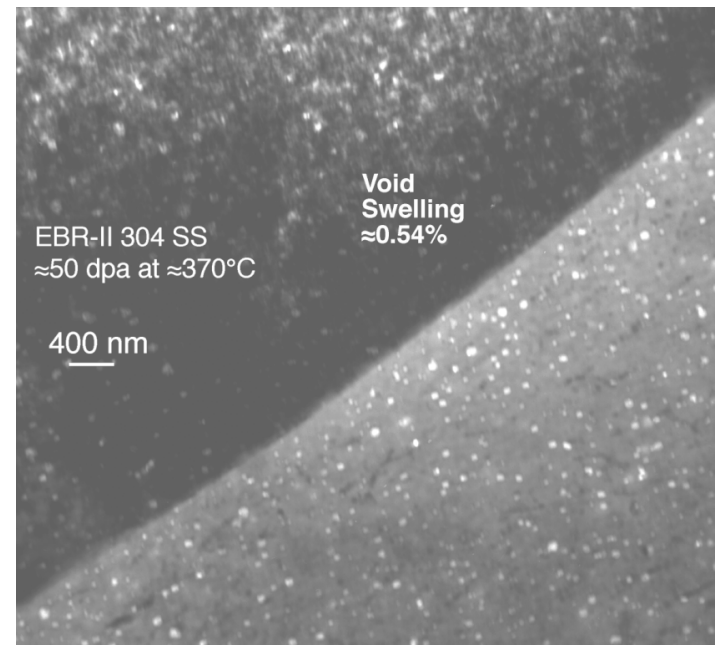

(a)

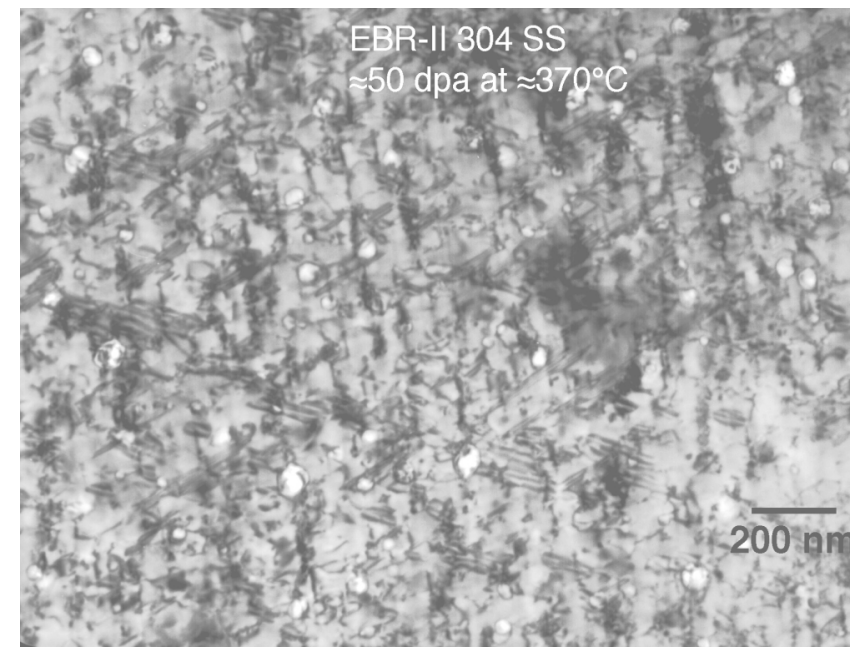

(b)

Figure 5. Microstructure of SA Type $304 \mathrm{SS}$ fuel subassembly hex can irradiated in EBR-II at $370^{\circ} \mathrm{C}$ to 50 dpa (from Ref. 13); (a) voids near grain boundary, (b) high magnification, (c) voids and twins in low magnification, and (d) dark-field image of dense carbide precipitates. 


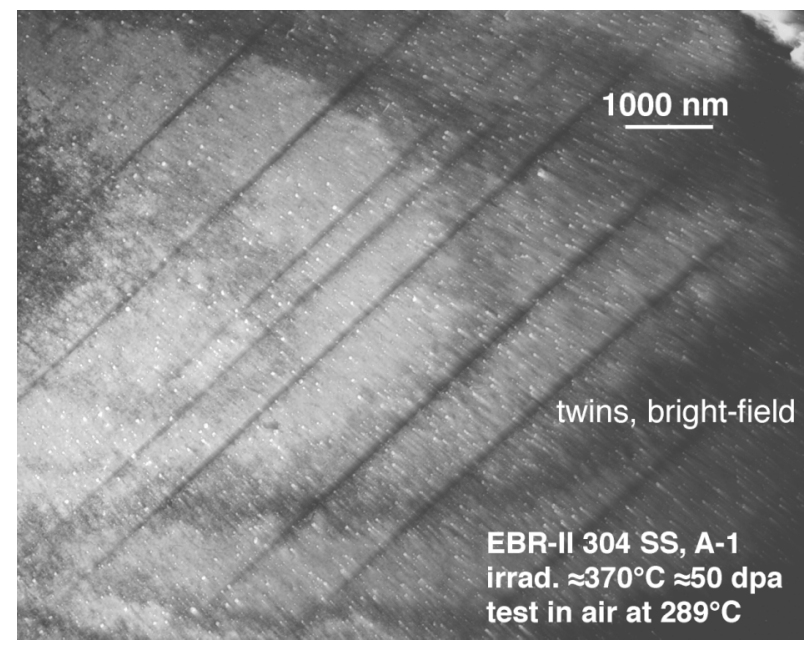

(c)

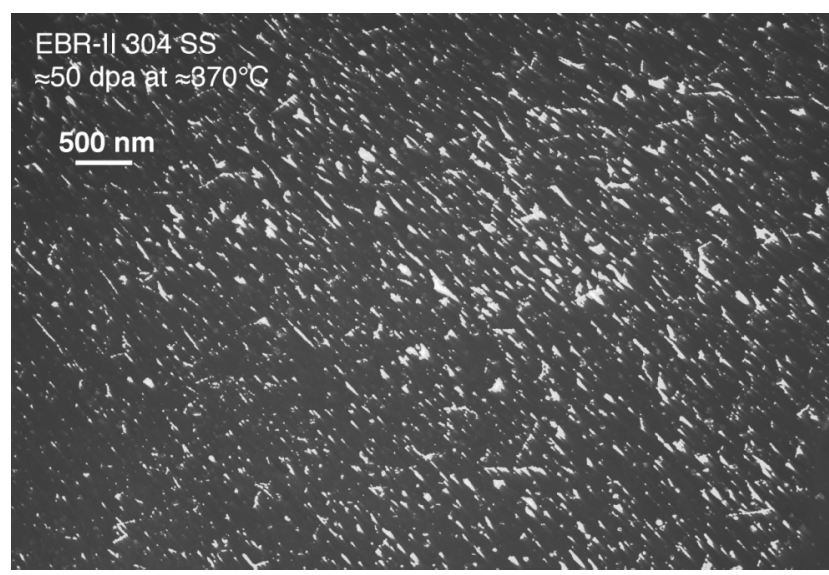

(d)

Figure 5. (Contd.)

\subsection{Swelling in Steels Irradiated at $305-335^{\circ} \mathrm{C}$ in $\mathrm{BN}-350$ at Dose Rates Comparable to PWR Dose Rates}

BN-350 is a sodium-cooled fast breeder reactor (FBR) located in Kazakhstan. Void swelling behavior of a Ti-containing steel similar to AISI $321 \mathrm{SS}$ was investigated by Porollo et al. after irradiation at $305-355^{\circ} \mathrm{C}$ at dose rates between $11.2 \times 10^{-9}$ and $156 \times 10^{-9} \mathrm{dpa} / \mathrm{s} .{ }^{14}$ The lower range of dose rate is comparable to those of a flux thimble tube, core barrel, and baffle former in a western PWR (see Table 3 ). The higher dose rate is comparable to the dose rate of a PWR reentrant corner. The experiment was performed with a flow restricter of the reactor, which was fabricated from a Russian Type X18H10T steel (composition in wt.\%: $18.5 \mathrm{Cr}, 9.5 \mathrm{Ni}, 1.5 \mathrm{Mn}, 0.7 \mathrm{Si}, 0.6 \mathrm{Ti}$, and $\leq 0.12 \mathrm{C}$ ). The component was irradiated continuously for $5.3 \mathrm{y}$ without interruption.

Void swelling under all examined conditions was $<0.98 \%$. Swelling at $\leq 307^{\circ} \mathrm{C}$ was too low to measure. Figure 6 shows void swelling for irradiation temperatures in the range of $311-313^{\circ} \mathrm{C}$. Note that in the constant-time irradiation, dose, dose rate, and specimen temperature vary, depending on the

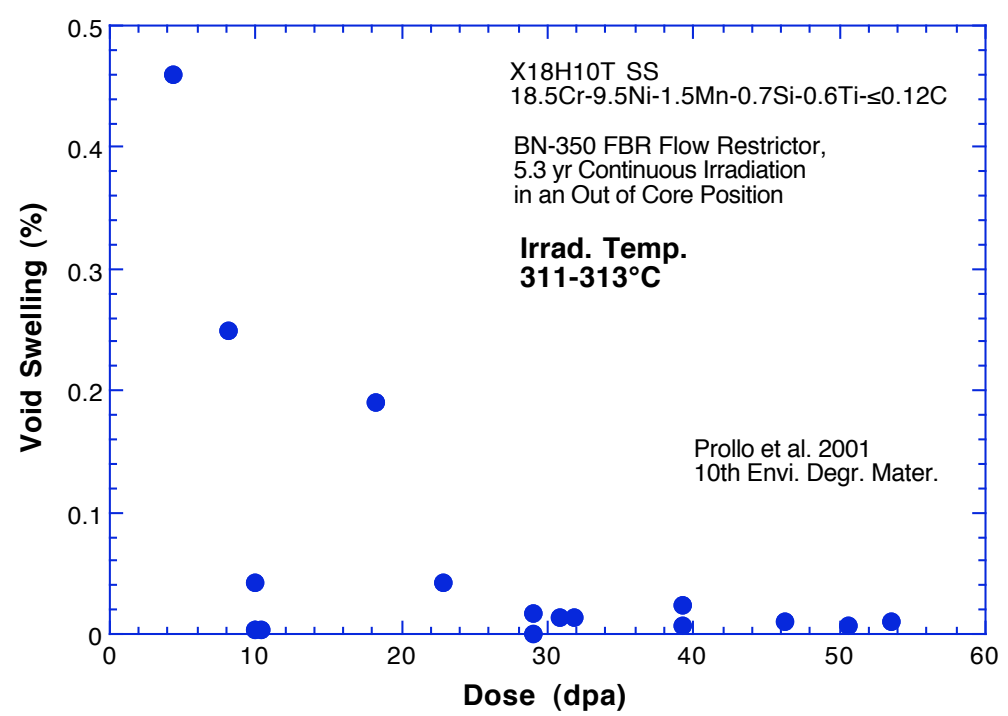

Figure 6.

Void swelling in Ti-containing Russian steel after 5.3 y in BN-350 breeder at $311-313^{\circ} \mathrm{C}(3-53 \mathrm{dpa})$ (from Ref. 14). 
location of the specimen. Although the swelling was low, i.e., $<0.5 \%$, it exhibits the trend that swelling at a lower dose rate (hence lower dose) is higher than at higher dose rate (hence higher dose).

This observation provides strong evidence that even for a given irradiation temperature for a particular steel, the integral effects of dose and dose rate cannot be separated. Therefore, it would be incorrect to extrapolate swelling data on the basis of "progressive compounded multiplication" of the separate effects of dose, dose rate, and temperature.

\subsection{Effect of Irradiation-Induced Precipitation}

Irradiation-induced precipitation leads to profound modification of microstructure. Similar to irradiation-induced segregation which is a precursor process, irradiation-induced precipitation is sensitive to steel type, minor alloying and impurities, irradiation temperature, dose, and dose rate.

For a given material irradiated to the same damage level, the degree of irradiation-induced segregation and irradiation-induced precipitation is sensitive to temperature and dose rate. ${ }^{15,16}$ This behavior is schematically illustrated in Fig. 7. Irradiation-induced precipitation is difficult to predict theoretically for a given material under a given irradiation condition. However, it is well known that, as irradiation temperature decreases, the size of the irradiation-induced precipitate decreases strongly and number density increases strongly (see Fig. 7).

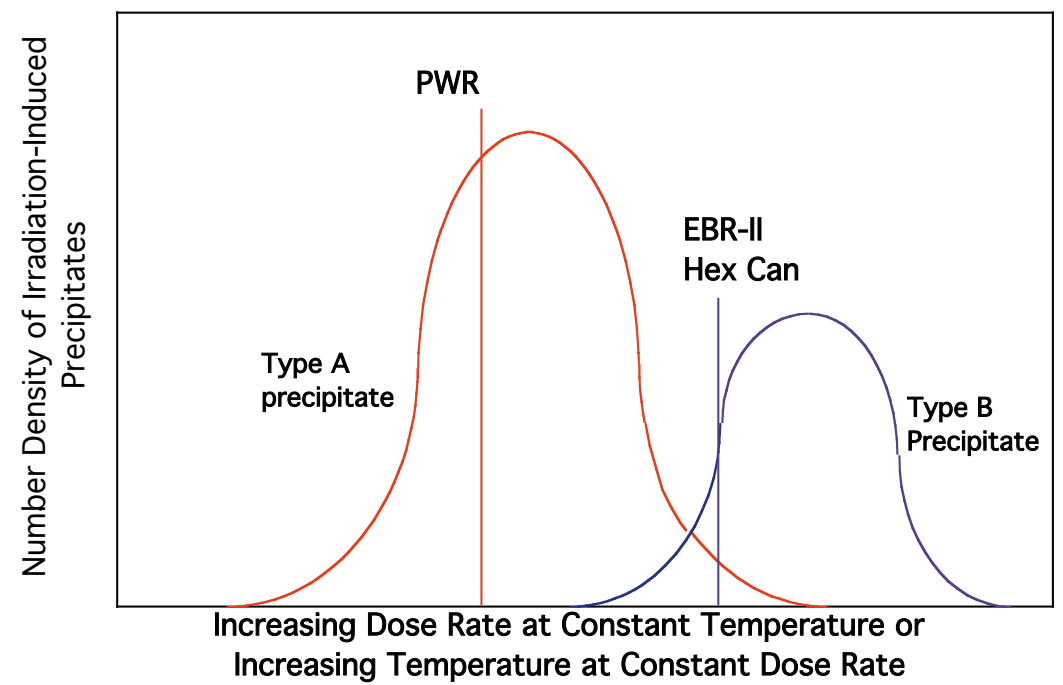

Figure 7. Schematic illustration of characteristics of irradiation-induced precipitation sensitive to dose rate and irradiation temperature.

In austenitic SSs, several types of irradiation-induced precipitation occur under neutron irradiation, e.g., $\mathrm{G}$ phase, $\mathrm{M}_{23} \mathrm{C}_{6}, \mathrm{TiC}, \mathrm{NbC}$, and $\gamma^{\prime}$ precipitation. Sometimes, epsilon martensites have been reported in a heavily swelled Type 304L steel. However, martensite precipitation is thought to be driven by the local deformation in the heavily swelled region rather than by an irradiation-induced process.

Irradiation-induced precipitates at the PWR-relevant temperatures of $290-380^{\circ} \mathrm{C}$ are extremely small (i.e., a few to several tens of nanometers), and the number density is extremely high. Therefore, irradiation-induced precipitation at low temperatures creates an extremely large internal surface, i.e., the interface between the steel matrix and the precipitates. Such interface acts as a sink to irradiation-induced vacancies, thereby suppressing the agglomeration of the vacancies. Because of this, nucleation and 
growth of voids are greatly suppressed when irradiation-induced precipitates are produced in high number density. This behavior has been known well for vanadium-based alloys, a group of alloys being developed for fusion reactor structural materials. Although unalloyed vanadium exhibits large swelling, a Ti-containing vanadium alloy, which usually contains a significant level of $\mathrm{Si}, \mathrm{O}, \mathrm{N}$, and $\mathrm{C}$ as impurities, is highly resistant to swelling. This behavior has been investigated extensively and attributed to highdensity precipitation of very fine Ti silicides. ${ }^{17-19}$

Figure 8 (from Ref. 16) is a schematic representation of the relationship between void swelling and the number density of irradiation-induced precipitates. For a given material at a given temperature, three types of kinetics of irradiation-induced precipitation are shown in Fig. 8a: no precipitation (Case I), slow (Case II), and fast kinetics (Case III). Void swelling behaviors expected for the three cases are illustrated in Fig. 8b. This model predicts that swelling in a complex material such as an austenitic SS will be strongly influenced by the factors that control the kinetics of irradiation-induced precipitation, i.e., alloying and impurity elements, temperature, dose rate, and dose.

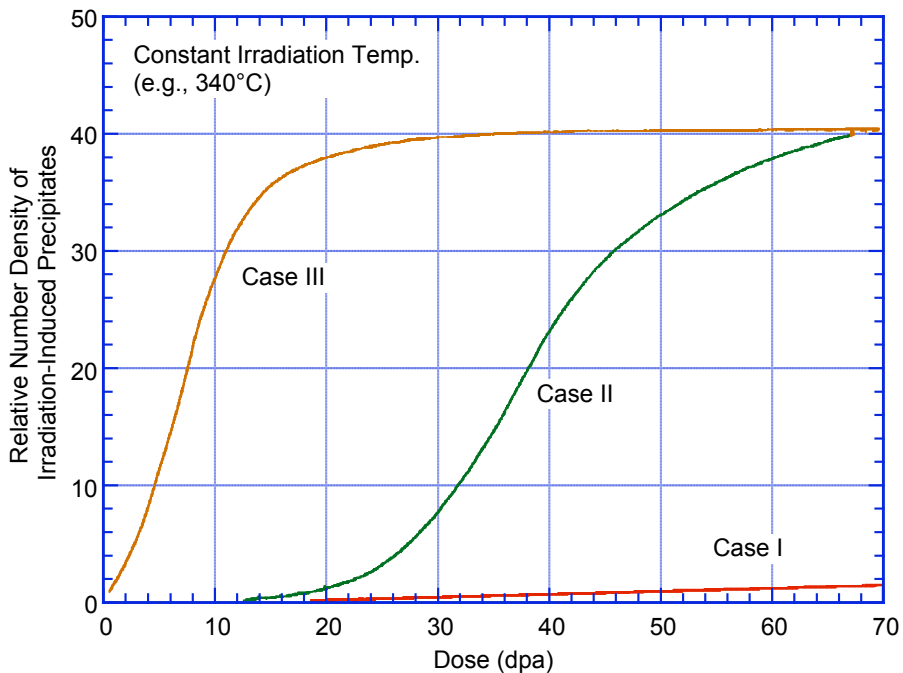

(a)

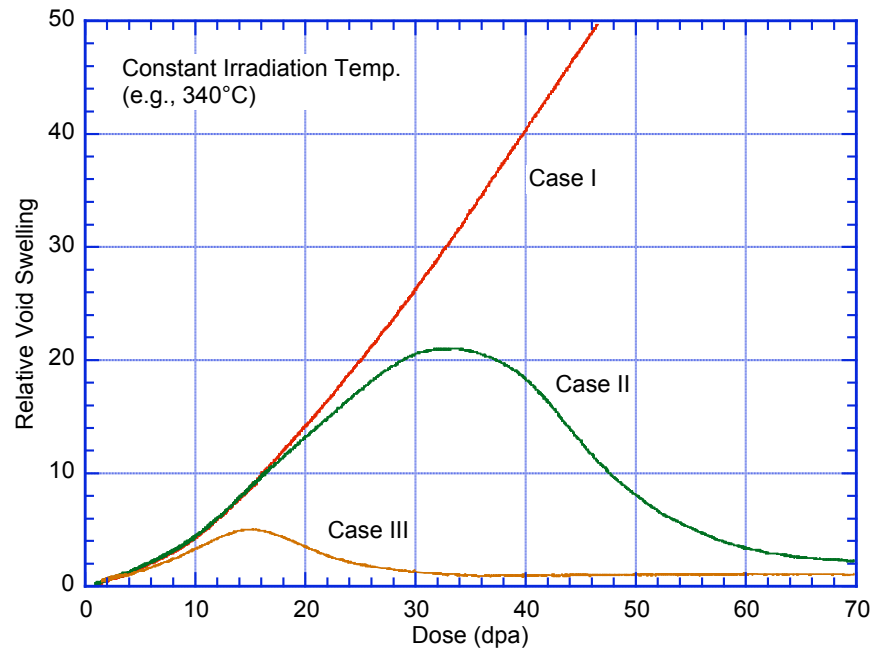

(b)

Figure 8. Schematic illustration of (a) three types of relationship between irradiation-induced precipitation and (b) void swelling as a function of irradiation dose (From Ref. 19). 


\subsubsection{Low Swelling of CW Type 316 SS and High-Density Precipitation of $\boldsymbol{\gamma}^{\prime}$ and an Unidentified Phase in PWR Baffle Bolts}

A good correlation between low swelling and high-density precipitation is observed for CW Type 316 SS from the behavior of Tihange baffle bolts (void swelling $\approx 0.24 \%$ after irradiation to $7.5 \mathrm{dpa}$, see Section 2.4). The distribution of voids and high-density precipitation of $\gamma^{\prime}$ phase is shown in Fig. 9 (from Ref. 5). In addition to $\gamma^{\prime}$ phase, unknown precipitates were also observed.

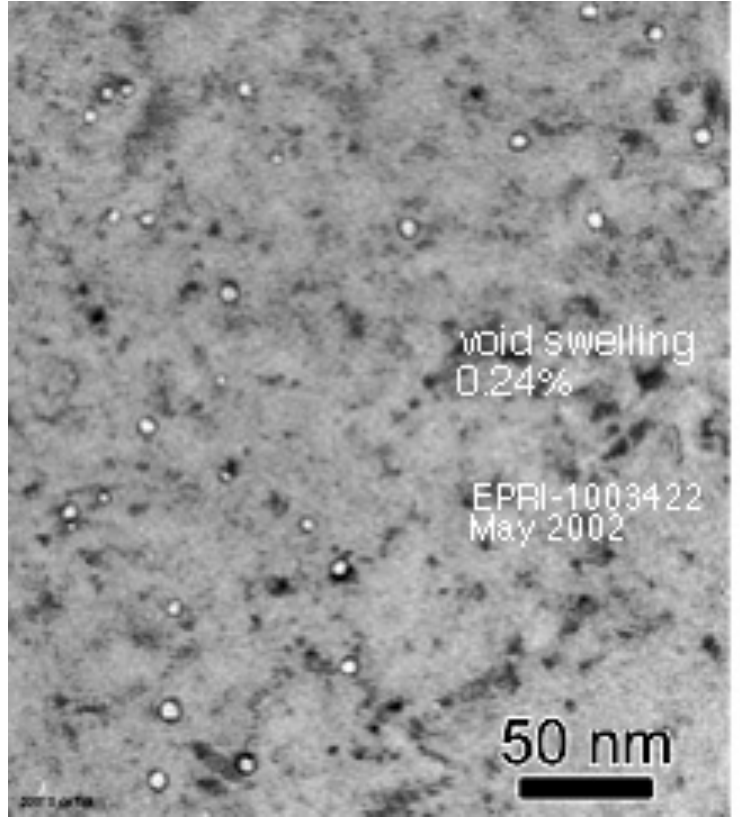

(a)

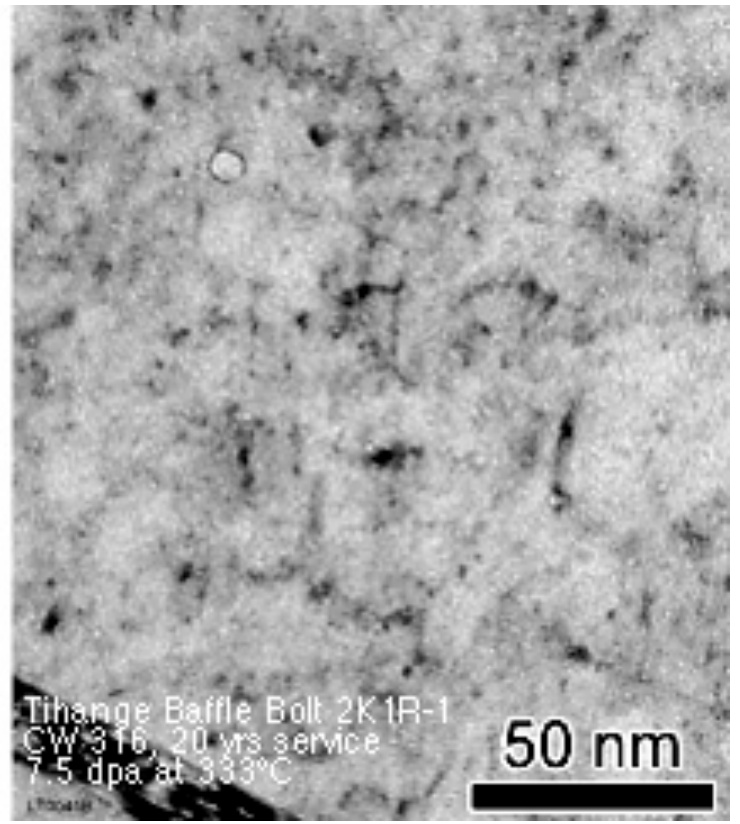

(b)

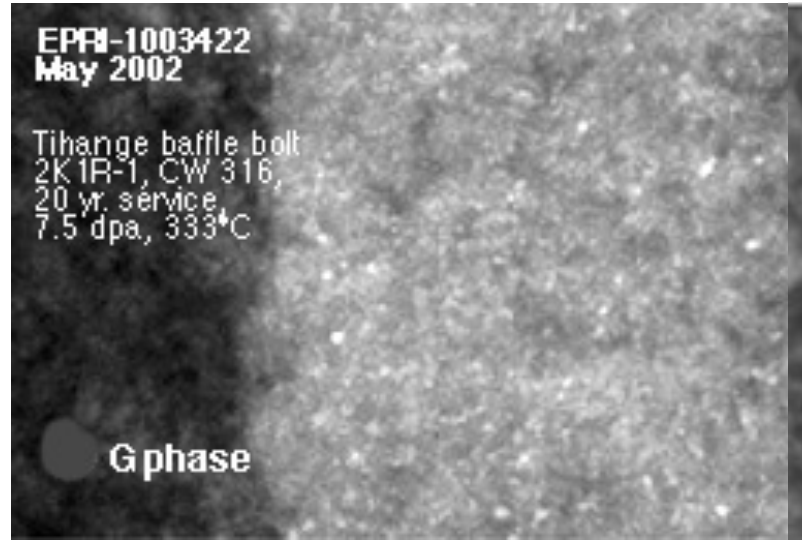

(c)

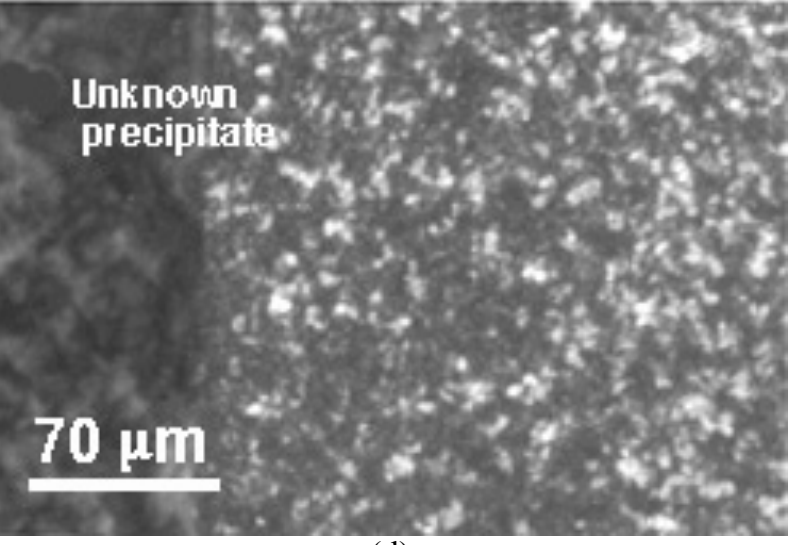

(d)

Figure 9. Low void swelling ( $a$ and b) and high-density precipitation of $\gamma$ ' phase (c) and unknown phase (d) in the Tihange PWR baffle bolt fabricated from CW Type 316 SS $(0.24 \%$ swelling at 7.5 dpa, from Ref. 5).

\subsubsection{Low Swelling in $\mathbf{3 4 8}$ SS and Dense Precipitation of NbC in a PWR}

Good correlation between low void swelling and dense precipitation of very fine NbC phase is observed from the microstructure of SA348 SS reported by Garzarolli et al. ${ }^{20}$ The authors examined a $\mathrm{B} 4 \mathrm{C}$-filled tube similar to a control rod cladding after irradiation to $\approx 10 \mathrm{dpa}$ at $\approx 325^{\circ} \mathrm{C}$ near the core 
center of a PWR. Void swelling shown in Fig. 3 (left) of their report is insignificant (i.e., $<0.05 \%$ ), and $\mathrm{NbC}$ precipitates are observed in very high density.

\subsubsection{Low Swelling and Dense Precipitates in SA Type 304 Irradiated to $50 \mathrm{dpa}$ at $370^{\circ} \mathrm{C}$ in EBR-II at Dose Rate Relevant to PWR Reentrant Corner}

Good correlation between low void swelling and dense precipitation of an unidentified phase is observed from the microstructure shown in Fig. 5 in Ref. 13. The material (SA Type 304 SS) and the irradiation temperature $\left(\approx 370^{\circ} \mathrm{C}\right)$ in this study are similar to those of PWR reentrant corners.

\subsubsection{Low Density Change and High-Density Precipitation in CW Type 316 SS Irradiated to 23-51 dpa at $375-430^{\circ} \mathrm{C}$ in EBR-II at Dose Rate Relevant to PWR Reentrant Corner}

Various types of precipitates were reported by Cole et al. ${ }^{21}$ for the CW $316 \mathrm{SS}$ hex can that exhibited low swelling (density change) after irradiation to $23-51 \mathrm{dpa}$ at $376-430^{\circ} \mathrm{C}$ in EBR-II at dose rates relevant to PWR reentrant corners (see Fig. 4, Section 3.3). The observed precipitates include Tirich precipitates, carbides $\left(\mathrm{M}_{6} \mathrm{C}, \mathrm{M}_{23} \mathrm{C}_{6}\right.$, and $\left.\mathrm{M}_{7} \mathrm{C}_{3}\right)$, S-rich precipitates, and extremely small $(<10 \mathrm{~nm})$ Fe-rich intermetallics. Direct correlation between the density change and the distribution of the precipitates (e.g., dark-field images of the various types of precipitates) was, however, not provided.

\subsubsection{Low Swelling and High-Density Precipitation of G Phase and TiC in X18H10T SS Irradiated in $\mathrm{BN}-350$ at $305-355^{\circ} \mathrm{C}$ at Dose Rates Relevant to PWRs}

Good correlation between the two phenomena is obvious in the microstructure shown in Ref. 14. A similar behavior is expected for the western counterpart AISI $321 \mathrm{SS}$.

\subsection{Swelling Behavior of Type 304L SS}

Void swelling has been known to be higher in Type 304L SS than in Type 304 SS under similar conditions. This behavior may be related to the trend that high-density irradiation-induced precipitation of carbides is less likely to occur in Type 304L SS. However, most internals in a PWR are fabricated from SA Type 304, CW Type 316, CW Type 347, or CW Type 348 SSs rather than Type 304L SS.

\subsection{Steady-State Swelling Rate of $1 \% / d p a$}

The steady-state (or breakaway) swelling rate of $1 \% / \mathrm{dpa}$ has been observed for austenitic SSs at high dose if the swelling exceeds a threshold level; however, careful review of the data in Ref. 3 indicates that such behavior was observed for western steels only at high irradiation temperatures, i.e., $427-650^{\circ} \mathrm{C}$ for CW Type 316 irradiated in EBR-II, Fig. 3-6; 450, 500, and $550^{\circ} \mathrm{C}$ for SA316 irradiated in RAPSODIE FBR, Figs. 3-7 and 3-27; 590-610 ${ }^{\circ} \mathrm{C}$ for CW Type 316 irradiated in PHENIX FBR, Fig. 3-28; 538, 593, and $650^{\circ} \mathrm{C}$ for $\mathrm{Fe}-15 \mathrm{Cr}-\mathrm{Ni}$ ternary irradiated in EBR-II, Fig. $3-39 ; 400-538^{\circ} \mathrm{C}$ for $\mathrm{Fe}-\mathrm{Cr}-\mathrm{Ni}$ ternary irradiated in EBR-II, Fig. $3-40 ; 425^{\circ} \mathrm{C}$ for $316 \mathrm{SS}$ irradiated in the Dounreay FBR, Fig. $3-45 ; 450-538^{\circ} \mathrm{C}$ for Type 304L SS irradiated in EBR-II, Fig. 3-51; and 510-560 ${ }^{\circ} \mathrm{C}$ for Type 304 SS irradiated in EBR-II, Fig. 3-52. There is no evidence that the steady-state swelling rate of $1 \% / \mathrm{dpa}$ was observed for PWRrelevant temperatures of $<380^{\circ} \mathrm{C}$. 


\subsection{Threshold Swelling to Enter the Regime of Steady-State Swelling Rate}

The threshold swelling to enter the regime of steady-state swelling rate (commonly referred to as breakaway swelling rate) ranges from 3 to $5 \%$. However, as indicated above, there is no evidence that this threshold level of void swelling was reached in any experiment at PWR-relevant temperatures of $<380^{\circ} \mathrm{C}$. 


\section{Assessment of the Potential for Void Swelling for PWR Internals at EOL}

In Section 2, currently available data from several types of PWR internals were reviewed in detail. In all cases, void swelling was no greater than $0.42 \%$ for service temperatures $<343^{\circ} \mathrm{C}$ and for dose levels $<65$ dpa. In Section 3, void swelling and density change data from EBR-II components irradiated at $\leq 380^{\circ} \mathrm{C}$ at dose rates comparable to those of PWR internals were reviewed. Current understanding of important factors necessary to extrapolate swelling data from fast-breeder to PWR conditions was also reviewed. The review allows an initial assessment of EOL swelling for several types of PWR internals. This section discusses the implications of the observations from those two sections, and applies the recognized void swelling criteria to instrument tubes, baffle bolts and core formers - components that are exposed to the most aggressive combinations of flux and temperature, and should be lead items in the development of void swelling issues for PWRs.

\subsection{Thin-Walled Flux Thimble and Instrument Tubes}

The effect of gamma heating is insignificant in these components (mostly fabricated from CW 316 SS), which are in contact with coolant. Therefore, irradiation temperature during service is not expected to exceed $\approx 325^{\circ} \mathrm{C}$. The currently available database appears to be adequate to reach a conclusion that void swelling in this type of reactor internal is not a concern for the period of license extension.

\subsection{Baffle Bolts}

Most baffle bolts are fabricated from CW Type 316 SS. The database obtained from the industry baffle bolt program shows that swelling is insignificant for dose levels up to $\approx 20 \mathrm{dpa}$ and irradiation temperatures up to $\approx 340^{\circ} \mathrm{C}$. The database obtained on EBR-II components irradiated at $<380^{\circ} \mathrm{C}$ and at dose rates comparable to those of a baffle bolt is consistent with the data from the industry bolt program. The low void swelling in this class of steel seems to be related to irradiation-induced formation of very fine precipitates in very high number density. Given the data that is available at this time, it is not likely that void swelling in this type of internal will exceed the threshold level (i.e., $\approx 4 \%$ ) that is necessary to enter the regime of the steady-state swelling rate of $1 \% / \mathrm{dpa}$, including the period of operation during license extension.

\subsection{Baffle Plate Reentrant Corners}

This type of reactor internal is primarily fabricated from SA Type 304 SS and is most susceptible to high swelling rates. The maximum irradiation temperature in some regions of a reentrant corner has been estimated to be in the range of $\approx 380-420^{\circ} \mathrm{C}$. Although further studies are needed to more accurately calculate the temperature for EOL and life-extension conditions, $\approx 380^{\circ} \mathrm{C}$ is believed to be a more likely upper limit.

No database is available for a comparable material irradiated under the PWR condition. Only one investigation has been reported for void swelling in this class of material after irradiation in EBR-II at $370^{\circ} \mathrm{C}$ to $\approx 50 \mathrm{dpa}$ at a dose rate comparable to that of a PWR reentrant corner. Void swelling in this material was only $0.54 \%$. The low swelling is believed to be related to high-density irradiation-induced precipitation of very fine carbides. 
It is not likely that void swelling in this type of reactor internal will exceed the threshold level of swelling of $\approx 4 \%$ that is necessary to enter the regime of the steady-state swelling rate of $1 \% / \mathrm{dpa}$, including the period of license extension. However, this estimation is only preliminary; more data from SA Type 304 SS at PWR-relevant dose rates and a better mechanistic understanding are needed. More accurate quantification of maximum irradiation temperature at EOL and life-extension situations is recommended. Specimens of SS and nickel-base alloys are currently being irradiated at applicable temperatures in an attempt to provide a more extensive database for void swelling effects. The results of these programs are in the early stages of publication; more results are expected flow steadily for the next few years. 


\section{Summary and Conclusions}

The study of void swelling for LWR conditions is very much a work in progress, and a considerable body of results is expected to emerge over the next several years. At this juncture, neither the reasonable extrapolation of results from higher temperatures and higher dose rates, nor the small but growing body of examinations of salvaged light-water reactor core internal materials suggests that void swelling will be a significant problem during the first license extension period for the current fleet. The following observations and conclusions are based on this information:

1. At this time, the database of void swelling for PWR internals that can be used to directly evaluate the behavior at end-of-life (EOL) and life-extension situations is very limited. However, significant data are available for thin-walled internals such as flux thimble tubes.

2. Most swelling data that are available were obtained from steels irradiated in fast breeder reactors at temperatures $>385^{\circ} \mathrm{C}$ and at dose rates that are orders of magnitude higher than PWR dose rates. Extreme care must be exercised when interpreting and extrapolating such data. These data should not be extrapolated to determine credible void swelling behavior for PWR EOL or life-extension conditions.

3. Even for a given irradiation temperature and given steel, the integral effects of dose and dose rate on void swelling cannot be separated. Unless it is demonstrated that interaction effects are small, it can be misleading to extrapolate swelling data on the basis of "progressive compounded multiplication" of separate effects of factors such as dose, dose rate, temperature, and material composition.

4. Limited swelling data are available for CW $316 \mathrm{SS}$ irradiated to $53 \mathrm{dpa}$ at $376-386^{\circ} \mathrm{C}$ and for solution-annealed Type $304 \mathrm{SS}$ irradiated to $50 \mathrm{dpa}$ at $\approx 370^{\circ} \mathrm{C}$ in EBR-II reflector positions at dose rates comparable to those of PWR reentrant corners. As such, these data are relevant to the conditions of PWR reentrant corners. Swelling in these materials was less than $\approx 1 \%$.

5. Low void swelling observed in the PWR components and in the EBR-II steels under PWR-relevant dose rates appears to be associated with irradiation-induced formation of very fine precipitates (such as $\mathrm{G}$ phase, carbides, and $\gamma^{\prime}$ phase) in high number density. Such irradiation-induced precipitation at low temperatures $\left(<370^{\circ} \mathrm{C}\right)$ creates an extremely large internal surface, i.e., the interface between the steel matrix and the precipitates. Such interface acts as an efficient sink to irradiation-induced vacancies, thereby suppressing the agglomeration of the vacancies. Irradiation-induced precipitation is sensitive to minor alloying and impurity elements, irradiation temperature, and dose rate.

6. In thin-walled flux thimbles and instrument tubes, the effect of gamma heating is insignificant. The currently available database is sufficient to conclude that void swelling in this type of reactor internal, mostly fabricated from CW $316 \mathrm{SS}$, is not an issue.

7. Most baffle bolts are fabricated from CW $316 \mathrm{SS}$. The data obtained from the industry baffle bolt program show that swelling is insignificant $(<0.25 \%)$ for dose levels up to $\approx 20$ dpa and irradiation temperatures of up to $\approx 340^{\circ} \mathrm{C}$. Data obtained on EBR-II components irradiated at temperatures $<380^{\circ} \mathrm{C}$ and at comparable dose rates are consistent with the data from the industry bolt program. Microstructural characteristics of the two groups of materials are also consistent. It is not likely that void swelling in this type of reactor internal will exceed the threshold level (i.e., $\approx 4 \%$ ) that is necessary to enter the regime of the steady-state swelling rate of 1\%/dpa.

8. Most baffle reentrant corners are fabricated from SA Type 304 SS and are most susceptible to high swelling rate, and hence, high swelling at EOL. The maximum irradiation temperature in some regions of 
the reentrant corners has been estimated to be in the range of $\approx 380-420^{\circ} \mathrm{C}$. Only one investigation has reported void swelling for this class of steel after irradiation in EBR-II at $370^{\circ} \mathrm{C}$ to $\approx 50 \mathrm{dpa}$ at a dose rate comparable to that of reentrant corners. Void swelling in this material was only $0.54 \%$. The low swelling appears to be related to high-density irradiation-induced precipitation of very fine carbides. Therefore, as a very preliminary conclusion, it is considered unlikely that void swelling in reentrant corners will exceed the threshold level of $\approx 4 \%$. More relevant data, especially a more accurate quantification of the maximum temperature throughout the operating life and life-extension situations of core support components, are needed for this class of steel. Also, needed is a better mechanistic understanding of the roles of irradiation-induced microstructural evolution on void swelling. 


\section{References}

1. Garner, F. A., "Chapter 6 - Irradiation Performance of Cladding and Structural Steels in Liquid Metal Reactors," Nuclear Materials, Part 1, Vol. 10A, edited by B. R. T. Frost, in Maaterials Science and Technology, - A Comprehensive Treatment, edited by R. W. Cahn, P. Haasen and E. J. Kramer, and published by VCH Verlagsgesellschaft mbH, Weinheim, Germany.

2. MRP-73, "Materials Reliability Program Characterization of Type 316 Cold-Worked Stainless Steel Highly Irradiated under PWR Operating Conditions," EPRI-1003525, August 2002.

3. MRP-50, "Materials Reliability Program Technical Basis Document Concerning IrradiationInduced Stress Relaxation and Void Swelling in Pressurized Water Reactor Vessel Internals Components," EPRI-1000970, Interim Report, October 2001

4. Byrne, S., F. A. Garner, S. Fyfitch, and I. L. Wilson, "Application of Void Swelling Data to Evaluation of Pressurized Water Reactor Components," Proc. 10th Intl. Conf. on Environmental Degradation of Materials in Nuclear Power Systems - Water Reactors, NACE/ANS/TMS, Aug. 5-9, 2001, Lake Tahoe, NV.

5. Edwards, D. J., F. A. Garner, B. A. Oliver, and S. M. Bruemmer, "Microstructural Evaluation of a Cold-Worked 316SS Baffle Bolty Irradiated in a Commercial PWR," Proc. 10th Intl. Conf. on Environmental Degradation of Materials in Nuclear Power Systems - Water Reactors, NACE/ANS/ TMS, Aug. 5-9, 2001, Lake Tahoe, NV.

6. Thomas, L., and S. Bruemmer, "Analytical Transmission Microscopy (ATEM) Characterization of Stress Corrosion Cracks in LWR-Irradiated Austenitic Stainless Steel Components," EPRI1003422, Electric Power Research Institute, Palo Alto, CA, May 2002.

7. Garner, F. A., B. M. Oliver, L. B. Greenwood, D. J. Edwards, S. Bruemmer, and M. L. Grossbeck "Generation and Retention of Helium and Hydrogen in Austenitic Steels Irradiated in a Variety of LWR and Test-Reactor Spectral Environments," Proc. 10th Intl. Conf. on Environmental Degradation of Materials in Nuclear Power Systems - Water Reactors, NACE/ANS/TMS, Aug. 5-9, 2001, Lake Tahoe, NV.

8. Fujii, K., K. Fukuya, G. Furutani, T. Torimaru, A. Kohyama, and Y. Katoh, "Swelling in 316 Stainless Steel Irradiated to $53 \mathrm{dpa}$ in a PWR," Proc. 10th Intl. Conf. on Environmental Degradation of Materials in Nuclear Power Systems - Water Reactors, NACE/ANS/TMS, Aug. 5-9, 2001, Lake Tahoe, NV.

9. Foster, J. P., D. L. Potter, D. L. Harrod, T. R. Mager, and M. G. Burke, “316 Stainless Steel Cavity Swelling in a PWR,” J. Nucl. Mater. 224, p. 207 (1995).

10. Mansur, L. K., "Theory and Experimental Background on Dimensional Changes in Irradiated Alloys," J. Nucl. Mater., 216 (1994) pp. 97-123.

11. Busboom, H. J., G. C. McClellan, W. L. Bell, and W. K. Appleby, "Swelling of Types 304 and 316 Stainless Steel Irradiated to $8 \times 10^{22} \mathrm{n} / \mathrm{cm}^{2}$," General Electric Co. Report GEAP-14062, Sunnyvale, CA, 1975. 
12. Allen, T. R., H. Tsai, R. S. Daum, D. L. Porter, J. I. Cole, T. Yoshitake, N. Akasaka, T. Donomae, S. Mizuta, J. Ohta, K. Dohi, and H. Kusanagi, "Effects of Irradiation on the Swelling and Mechanical Properties of 316 Stainless Steel," Proc. 11 th Intl. Conf. on Environmental Degradation of Materials in Nuclear Power Systems - Water Reactors, Aug. 10-14, 2003, Stevenson, WA.

13. Chung, H. M., R. V. Strain, and W. J. Shack, "Tensile and Stress Corrosion Cracking of Type 304 Stainless Steel Irradiated to Very High Dose,” Nucl. Eng. Design, 208, pp. 221-234 (2001).

14. Porollo, S. I., Yu. V. Konobeev, A. M. Dvoriashin, V. M. Krigan, and F. A. Garner, "Determination of the Lower Temperature Limit of Void Swelling of Stainless Steels at PWR-Relevant Displacement Rates," Proc. 10th Intl. Conf. on Environmental Degradation of Materials in Nuclear Power Systems - Water Reactors, Aug. 5-9, 2001, Lake Tahoe, NV.

15. Okamoto, P. R., and L. E. Rehn, "Radiation-Induced Segregation in Binary and Ternary Alloys," J. Nucl. Mater. 83 (1979) pp. 2-23.

16. Nolfi, F. V., Editor, Phase Transformation During Irradiation, Elsevier Science Publishing Co., London, 1983.

17. Chung, H. M., B. L. Loomis, and D. L. Smith, "Irradiation-Induced Precipitation in Vanadium-Base Alloys Containing Titanium," in Effects of Radiation on Materials: 16th International Symposium, ASTM STP 1175, A. S. Kumar, D. S. Gelles, R. K. Nanstad, and T. A. Little, eds., American Society for Testing and Materials, Philadelphia, 1993, pp.1185-1200.

18. Chung, H. M., B. A. Loomis, and D. L. Smith, "Swelling and Structure of Vanadium-Base Alloys Irradiated in The Dynamic Helium Charging Experiment," in Effects of Radiation on Materials: 17th International Symposium, ASTM STP 1270, D. S. Gelles, R. K. Nanstad, A. S. Kumar, and E. A. Little, Eds., American Society for Testing and Materials, Philadelphia, 1996, pp. 1077-1087.

19. Chung, H. M., B. A. Loomis, and D. L. Smith, "Effect of Irradiation Damage and Helium on Swelling and Structure of Vanadium-Base Alloys," J. Nucl. Mater., 212-215 (1994), pp. 804-812.

20. Garzarolli, F., P. Dewes, R. Hahn, and J. L. Nelson, "Deformability of High-Purity Stainless Steels and Ni-Base Alloys in the Core of a PWR," in Proc. 6th Intl. Symp. on Environmental Degradation of Materials in Nuclear Power Systems - Water Reactors, August 1-5, 1993, San Diego, CA, R. E. Gold and E. P. Simonen, eds., The Minerals, Metals, and Materials Society, Warrendale, PA, 1993, pp. 607-613.

21. Cole, J. I., T. R. Allen, H. Tsai, S. Ukai, S. Mizuta, N. Akasaka, T. Donomae, and T. Yoshitake, "Swelling and Microstructural Evolution in 316 Stainless Steel Hexagonal Ducts Following LongTerm Irradiation in EBR-II," in Effects of Radiation on Materials: $20^{\text {th }}$ Intl. Symp., ASTM STP 1405, S. T. Rosinski, M. L. Grossbeck, T. R. Allen, and A. S. Kumar, Eds., American Society for Testing and Materials, West Conshohocken, PA 2001. 


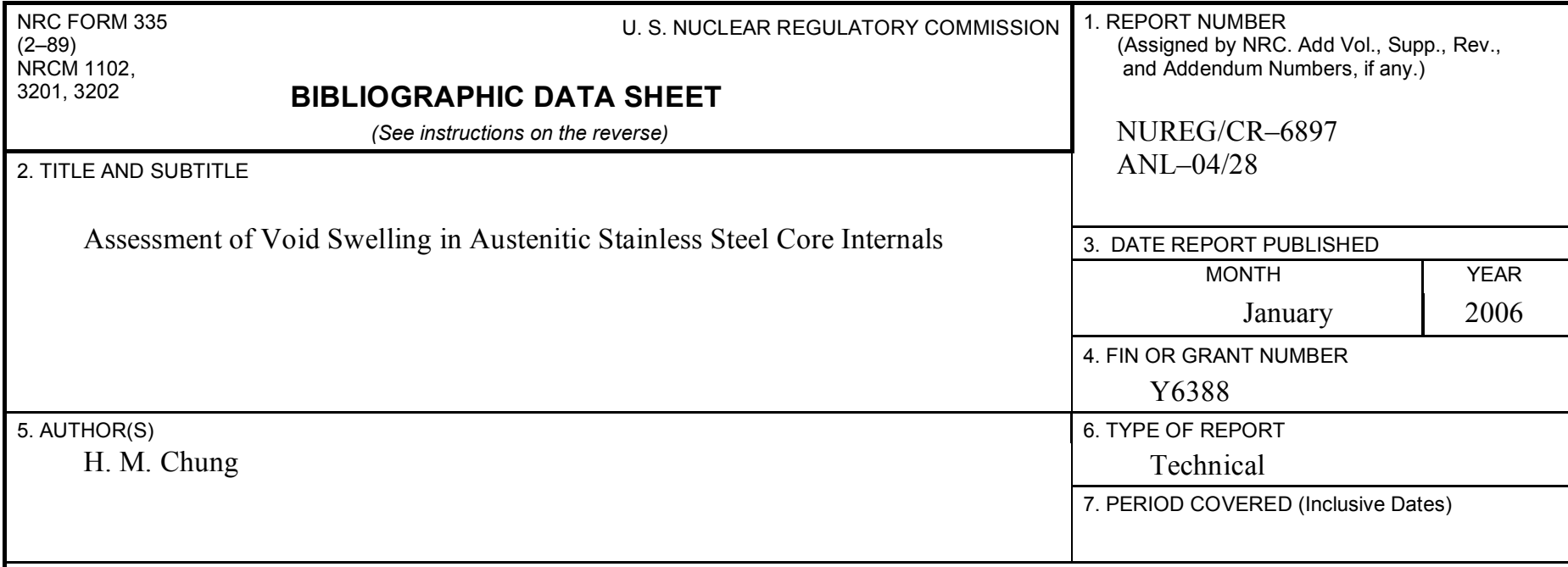

8. PERFORMING ORGANIZATION - NAME AND ADDRESS (If NRC, provide Division, Office or Region, U.S. Nuclear Regulatory Commission, and mailing address; if contractor, provide name and mailing address.)

Argonne National Laboratory

9700 South Cass Avenue

Argonne, IL 60439

9. SPONSORING ORGANIZATION - NAME AND ADDRESS (If NRC, type "Same as above": if contractor, provide NRC Division, Office or Region, U.S. Nuclear Regulatory Commission, and mailing address.)

Division of Engineering Technology

Office of Nuclear Regulatory Research

U.S. Nuclear Regulatory Commission

Washington, DC 20555-0001

10. SUPPLEMENTARY NOTES

William H. Cullen, Jr., NRC Project Manager

11. ABSTRACT (200 words or less)

As many pressurized water reactors (PWRs) age and life extension of the aged plants is considered, void swelling behavior of austenitic stainless steel (SS) core internals has become the subject of increasing attention. In this report, the available database on void swelling and density change of austenitic SSs was critically reviewed. Irradiation conditions, test procedures, and microstructural characteristics were carefully examined, and key factors that are important to determine the relevance of the database to PWR conditions were evaluated. Most swelling data were obtained from steels irradiated in fast breeder reactors at temperatures $>385^{\circ} \mathrm{C}$ and at dose rates that are orders of magnitude higher than PWR dose rates. These data cannot be extrapolated to determine credible void swelling behavior for PWR end-of-life (EOL) or lifeextension conditions. Limited amount of swelling data and information on microstructural characteristics are available that were obtained from discharged PWR internals or steels irradiated at temperatures and at dose rates comparable to those of a PWR. Based on the information, swelling in thin-walled tubes and baffle bolts in a PWR is not considered a concern. PWR baffle reentrant corners are most susceptible to high swelling rates, and hence, high swelling at EOL, especially in limited regions where irradiation temperature is high. However, this estimation is only preliminary, and a more accurate quantification of maximum temperature of reentrant corners at EOL and life-extension situations is needed.

12. KEY WORDS/DESCRIPTORS (List words or phrases that will assist researchers in locating this report.)

Void swelling

Austenitic stainless steels

PWR Environment

13. AVAILABILITY STATEMENT
Unlimited
14. SECURITY CLASSIFICATION
(This Page)
Unclassified
(This Report)
Unclassified
15. NUMBER OF PAGES
16.ICE PR

